\title{
Vapor Space Characterization of Waste Tank 241-BY-110: Results from Samples Collected on 11/11/94
}
T. W. Clauss
"M. W. Ligotke
K. H, Pool
B.'D. McVeety. T
R. B. Lucke
J. S. Young
G. S. Klingér
J. S. Fruchter
M. McCulloch
S. C. Goheen

June 1995

Prepared for Westinghouse Hanford Company under a Relăted Services Ágreemént with thê U.S. Department of Energy Contract DE-A'C06-76RLO 1830

\section{Pacific Northwest Laboratory}

Operated for the U.S. Department of Energy by Battélle Memorial Institute 


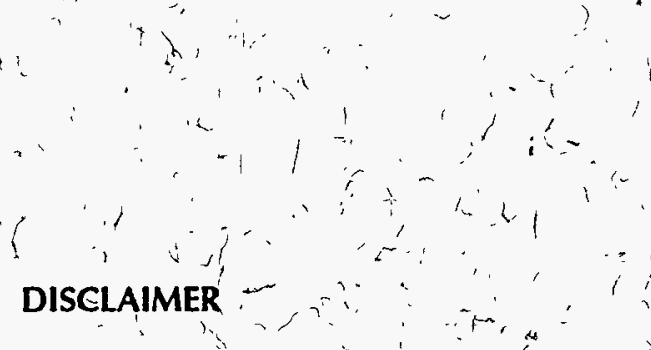

This report was prepared as an account of work sponsored by an agency of the United States Government. Neither the United States Government no'r any ágency thereof, nor Battelle Memorial Institute, nor any of théir employees, makes any, warranty, expressed or implied, or àssúmés any legal liabilițy or responsibility for the accuracy; completeness, or usefulness of any information, apparatus, product; , or process disclosed, or represents that its use would not infringe privately owned rights. Reference herein to any specific commercial product, process, or service by trade name, trademark, manufacturer, or otherwise does not necessarily constitute or imply its endorsemènt, recomméndation, or favioring by the United States Government or any agency thereof/or Battelle Memorial Institute. The views and opinions of authors expressed herein do not nécessarily state or reflect those of the United States Government or any agéncy thereof.

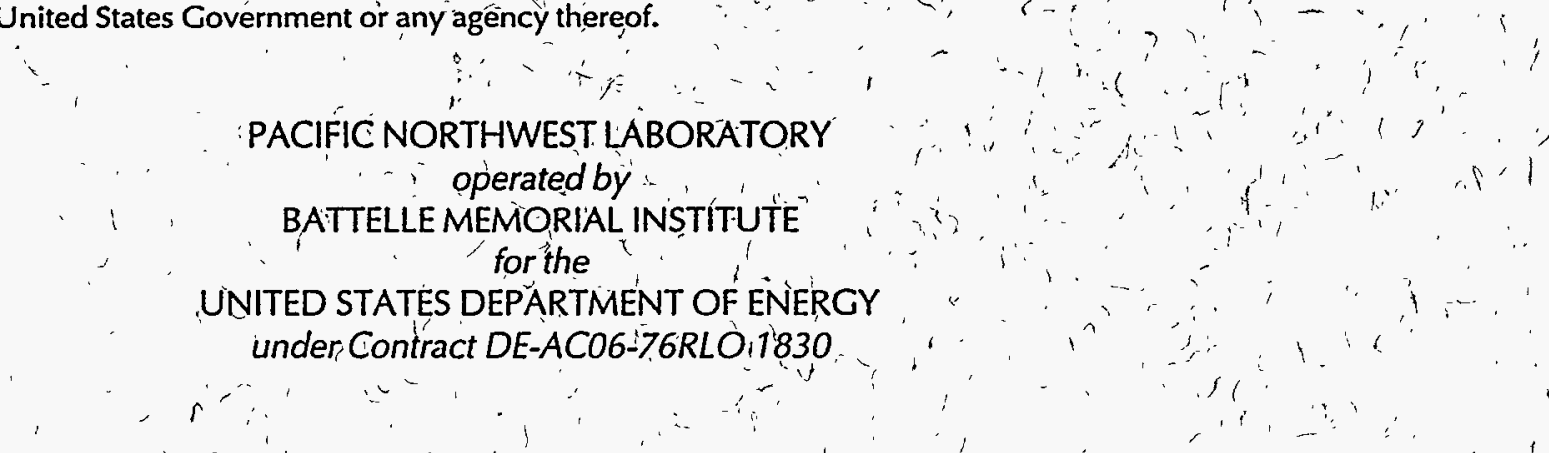

Printed in the United States of America

, , Available to DOE and DOE contractors from the Office of Scientific and Technical Information,'P.O.'Box 62, Oak Ridge, TN 37831; prices available from (615) 576-8401. FTS 626-8401.

Availàble to the publicifrom the National Technical Information Service, U.S. Department of Commerce, 5285 Port Royal Rd., Springfield, VA.22161. 
Vapor Space Characterization of Waste Tank 241-BY-110: Results from Samples Collected on 11/11/94

T. W. Clauss

M. W. Ligotke

K. H. Pool

R. B. Lucke

B. D. McVeety

G. S. Klinger

J. S. Young

M. McCulloch

J. S. Fruchter

S. C. Goheen

June 1995

Prepared for Westinghouse Hanford Company under a Related Services Agreement with the U.S. Department of Energy Contract DE-AC06-76RLO 1830

Pacific Northwest Laboratory

Richland, Washington 99352

DISTRIBUTTION GF THIG GEGUMENT IS UNLIMITED 


\section{DISCLAIMER}

Portions of this document may be illegible in electronic image products. Images are produced from the best available original document. 


\section{Summary}

This report describes inorganic and organic analyses results from samples obtained from the headspace of the Hanford waste storage Tank 241-BY-110 (referred to as Tank BY-110). The results described here were obtained to support safety and toxicological evaluations. A summary of the results for inorganic and organic analytes is listed in Table 1. Detailed descriptions of the results appear in the text.

Quantitative results were obtained for the inorganic compounds ammonia $\left(\mathrm{NH}_{3}\right)$, nitrogen dioxide $\left(\mathrm{NO}_{2}\right)$, nitric oxide (NO), and water $\left(\mathrm{H}_{2} \mathrm{O}\right)$. Sampling for hydrogen cyanide $(\mathrm{HCN})$ and sulfur oxides $\left(\mathrm{SO}_{\mathrm{X}}\right)$ was not requested. In addition, we looked for the $40 \mathrm{TO}-14$ compounds plus an additional 15 analytes. Of these, 10 were observed above the 5-ppbv reporting cutoff. Forty-six organic tentatively identified compounds (TICs) were observed above the reporting cutoff of (ca.) 10 ppbv, and are reported with concentrations that are semiquantative estimates based on internal standard response factors. The 10 organic analytes with the highest estimated concentrations are listed in Summary Table 1 and account for approximately $78 \%$ of the total organic components in Tank BY-110. Two permanent gases, carbon dioxide $\left(\mathrm{CO}_{2}\right)$ and nitrous oxide $\left(\mathrm{N}_{2} \mathrm{O}\right)$, were also detected.

\begin{tabular}{|c|c|c|c|}
\hline \multirow[b]{2}{*}{ Category } & \multicolumn{3}{|c|}{$\begin{array}{l}\text { Summary Results of Inorganic and Organic Samples Collec } \\
\text { from the Headspace of Tank BY-110 on } 11 / 11 / 94\end{array}$} \\
\hline & Analyte & $\begin{array}{l}\text { Vapor }{ }^{(a)} \\
\text { Concentration }\end{array}$ & Units \\
\hline Inorganic & $\begin{array}{l}\mathrm{NH}_{3} \\
\mathrm{NO}_{2} \\
\mathrm{NO} \\
\mathrm{H}_{2} \mathrm{O}\end{array}$ & $\begin{aligned} 401 & \pm 15 \\
& \leq 0.05 \\
& \leq 0.09 \\
9.2 & \pm 1\end{aligned}$ & $\begin{array}{l}\text { ppmv } \\
\text { ppmv } \\
\text { ppmv } \\
\mathrm{mg} / \mathrm{L}\end{array}$ \\
\hline Organic & $\begin{array}{l}\text { Acetone } \\
\text { Trichlorofluoromethane (FREON-11) } \\
\text { Butane } \\
\text { Propene } \\
\text { Pentane } \\
\text { 2-Butanone } \\
\text { 2-Methylpentane } \\
\text { Propane } \\
\text { 1-Butene } \\
\text { 2-Pentanone }\end{array}$ & $\begin{array}{r}25.69 \\
2.06 \\
1.75 \\
1.70 \\
1.57 \\
1.54 \\
1.19 \\
1.12 \\
0.95 \\
0.81\end{array}$ & $\begin{array}{l}\mathrm{mg} / \mathrm{m}^{3} \\
\mathrm{mg} / \mathrm{m}^{3} \\
\mathrm{mg} / \mathrm{m}^{3} \\
\mathrm{mg} / \mathrm{m}^{3} \\
\mathrm{mg} / \mathrm{m}^{3} \\
\mathrm{mg} / \mathrm{m}^{3} \\
\mathrm{mg} / \mathrm{m}^{3} \\
\mathrm{mg} / \mathrm{m}^{3} \\
\mathrm{mg} / \mathrm{m}^{3} \\
\mathrm{mg} / \mathrm{m}^{3}\end{array}$ \\
\hline
\end{tabular}

(a) Vapor concentrations were determined using sample-volume data provided by Westinghouse Hanford Company and are based on averaged data. The inorganic samples were obtained and analyzed using procedures that were subsequently improved. 



\section{Acknowledgments}

The authors gratefully acknowledge the support of other project staff at Pacific Northwest Laboratory who contributed to the successful completion of this sampling and analysis activity. Jeff Edwards served as the PNL single-point-of-contact and coordinated sample handling and communications with Westinghouse Hanford Company. K. B. Olsen assisted in preparing the organic portion of this report. Sally Slate, May-Lin Thomas and Karen Schielke analyzed inorganic samples, and Gary Dennis prepared the solid-sorbent sample trains. Bonnie L. Lehrman provided word processing support. 



\section{Abbreviations}

$\begin{array}{ll}\text { CAS } & \text { Chemical Abstracts Service } \\ \text { COC } & \text { chain of custody } \\ \text { C } & \text { concentration by volume } \\ \text { DIW } & \text { deionized water } \\ \text { emf } & \text { electromotive force } \\ \text { EPA } & \text { U.S. Environmental Protection Agency } \\ \text { GC/MS } & \text { gas chromatography/mass spectrometry } \\ \text { GC/TCD } & \text { gas chromatography/thermal conductivity detection } \\ \text { HP } & \text { Hewlett Packard } \\ \text { IC } & \text { ion chromatography } \\ \text { IL } & \text { impact level } \\ \text { IS } & \text { internal standard } \\ \text { MDL } & \text { minimum detection limit } \\ \text { NIST } & \text { National Institute for Standards and Technology } \\ \text { NPH } & \text { normal paraffin hydrocarbon } \\ \text { OSHA } & \text { Occupational Safety and Health Administration } \\ \text { PFA } & \text { perfluoroalkoxy } \\ \text { PNL } & \text { Pacific Northwest Laboratory } \\ \text { ppbv } & \text { part per billion by volume } \\ \text { Ppmv } & \text { part per million by volume } \\ \text { QA } & \text { quality assurance } \\ \text { REL } & \text { recommended exposure limit } \\ \text { RPD } & \text { relative percent difference } \\ \text { SCIC } & \text { suppressed-conductivity ion chromatography } \\ \text { SIE } & \text { selective ion electrode } \\ \text { SRM } & \text { standard reference material } \\ \text { STP } & \text { standard temperature and pressure } \\ \text { TEA } & \text { triethanolamine } \\ \text { TIC } & \text { tentatively identified compound } \\ \text { VSS } & \text { vapor sampling system } \\ \text { WHC } & \text { Westinghouse Hanford Company } \\ & \end{array}$




\section{Contents}

Summary $\ldots \ldots \ldots \ldots \ldots \ldots \ldots \ldots \ldots \ldots \ldots \ldots \ldots \ldots \ldots \ldots \ldots \ldots$ iii

Acknowledgments $\ldots \ldots \ldots \ldots \ldots \ldots \ldots \ldots \ldots \ldots \ldots \ldots \ldots \ldots \ldots \ldots$

Abbreviations $\ldots \ldots \ldots \ldots \ldots \ldots \ldots \ldots \ldots \ldots \ldots \ldots \ldots \ldots \ldots \ldots \ldots \ldots \ldots \ldots$

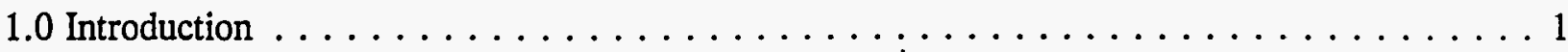

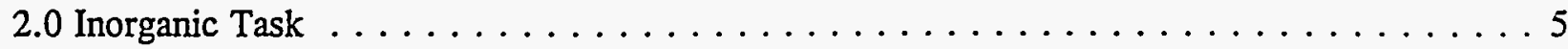

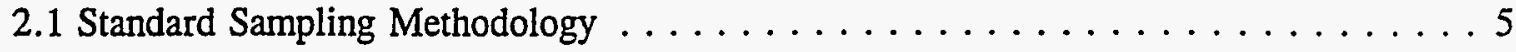

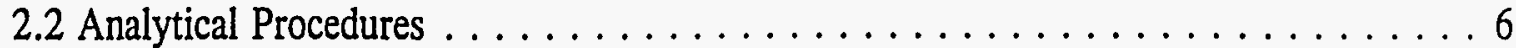

2.3 Quality Assurance/Quality Control . . . . . . . . . . . . . . . 8

2.4 Inorganic Sample Results . . . . . . . . . . . . . . . . 9

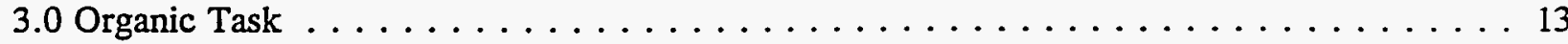

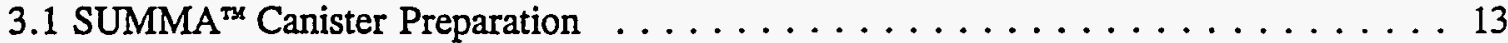

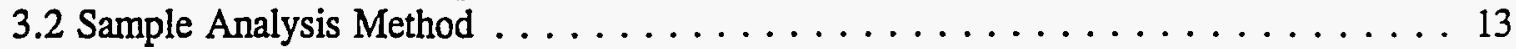

3.3 Quality Assurance/Quality Control . . . . . . . . . . . . . . . . . 14

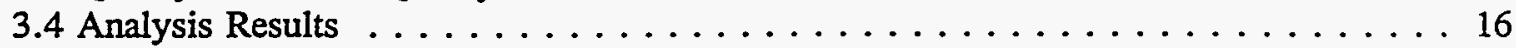

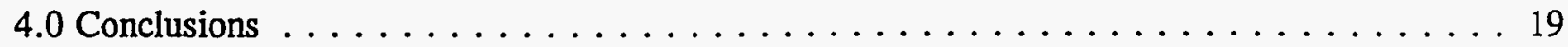

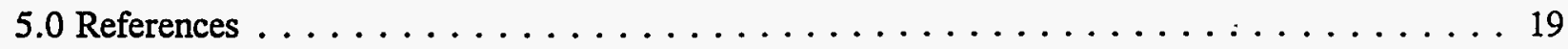

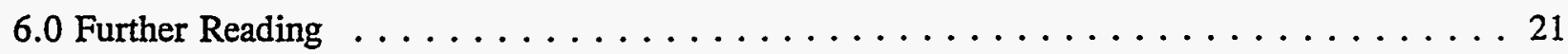

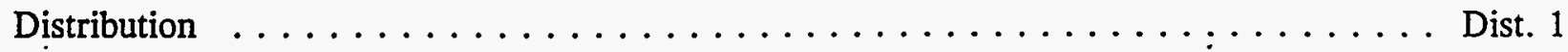




\section{Tables}

2.1 Analysis Procedures and Typical Detection Limits of Target Inorganic Analytes $\ldots \ldots$. . 8

2.2 List of PNL Inorganic Samples, Controls, and Gravimetric Results from a

Heated Tube Inserted into the Headspace of Tank BY-110 on $11 / 11 / 94 \ldots \ldots \ldots \ldots$

2.3 Inorganic Vapor Sample Results obtained from a Heated Tube Inserted into the

Headspace of Tank BY-110 on 11/11/94

3.1 Positively Identified and Quantitated T0-14 Target Analytes of Samples Collected

from the Headspace of Tank BY-110 in SUMMA ${ }^{\mathrm{Tx}}$ Canisters on $11 / 11 / 94 \ldots \ldots 22$

3.2 Tentatively Identified Compounds and Estimated Concentrations of Samples

from the Headspace of Tank BY-110 in SUMMA ${ }^{\text {TI }}$ Canisters Collected

on $11 / 11 / 94$

3.3 Positively Identified and Quantitated TO-14 Target Analytes of Replicate

Analyses of a Single SUMMA ${ }^{\text {Ts }}$ Canister Collected from the Headspace of

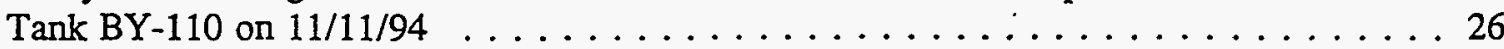

3.4 Tentatively Identified Compounds and Estimated Concentrations of Replicate

Analyses of a Single SUMMA ${ }^{\text {tx }}$ Canister Collected from the Headspace of

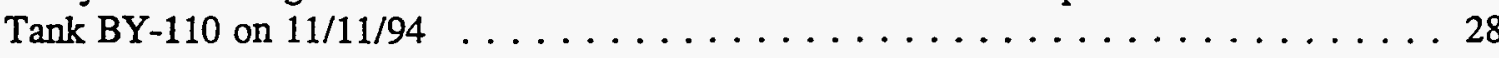

3.5 Positively Identified and Quantitated TO-14 Target Analytes for Ambient Air

Collected Near Tank BY-110 in SUMMA ${ }^{\text {nu }}$ Canisters on $11 / 11 / 94 \ldots \ldots \ldots$

3.6 Permanent Gas Analysis Results for Samples Collected from the

Headspace of Tank BY-110 and for Ambient Air Collected Near

Tank BY-110 in SUMMA ${ }^{\pi x}$ Canisters on 11/11/94

\section{Figures}

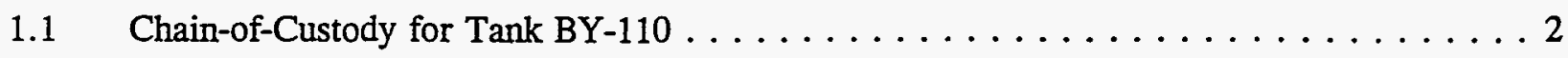

3.1 Total Ion Chromatogram of Hanford Waste Tank BY-110 SUMMA ${ }^{\text {Th }}$ Canister Sample

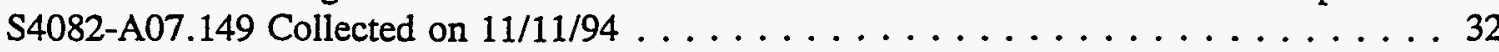




\subsection{Introduction}

This report describes results of the analyses of tank-headspace samples taken from the Hanford waste Tank 241-BY-110 (referred to as Tank BY-110). Pacific Northwest Laboratory (PNL) $)^{(a)}$ contracted with Westinghouse Hanford Company (WHC) to provide sampling devices and to analyze inorganic and organic analytes collected from the tank headspace and ambient air near the tank. The organic analytes for TO-14 compounds were extended to include 15 analytes identified by the Toxicological Review Panel for Tank C-103 and reported in 1994 by Mahlum et al. in Toxicological Evaluation of Analytes from Tank 241-C-103, PNL-10189. While these analytes (shown in Table 3.1) are only of toxicological concern for Tank C-103, program management included these analytes for future tank analyses as identified in the fiscal year work plan. This plan is attached to a letter dated 9/30/94 and addressed to Mr T. J. Kelly of WHC. The plan also requires PNL also to analyze for the permanent gases as shown in Table 3.5. The sample job was designated S4082, and samples were collected by WHC on November 11, 1994, using the vapor sampling system (VSS).

Sampling devices, including six sorbent trains (for inorganic analyses), and six SUMMA ${ }^{\text {TA }}$ canisters (for organic analyses) were supplied to the WHC sampling staff on November 10. Samples were taken (by WHC) from the tank headspace on November 11 and were returned to PNL from the field on November 28. Inorganic (sorbent trap) samples were delivered to PNL on chain-of-custody (COC) 008075 (Figure 1.1a). Additional $\mathrm{H}_{2} \mathrm{O}$ sorbent traps were included as shown on (COC) 008081 (Figure 1.1b). The SUMMA ${ }^{\text {mA }}$ canisters were delivered on COC 008074 (Figure 1.1c).

The samples were inspected upon delivery to the 326/23B laboratory and logged into PNL record book 55408 as described in PNL Technical Procedure PNL-TVP-07 ${ }^{(b)}$. Custody of the sorbent traps was transferred to PNL personnel performing the inorganic analysis and stored at refrigerated $\left(\leq 10^{\circ} \mathrm{C}\right.$ ) temperature until the time of analysis. The canister was stored in the 326/23B laboratory at ambient $\left(25^{\circ} \mathrm{C}\right)$ temperature until time of analysis. Access to the $326 / 23 \mathrm{~B}$ laboratory is limited to PNL personnel working on the waste-tank safety program. Analyses described in this report were performed at PNL in the 300 area of the Hanford Reservation. Analytical methods that were used are described in the text. In summary, sorbent traps for inorganic analyses containing sample materials were either weighed (for water analysis) or weighed and desorbed with the appropriate aqueous solutions (for ammonia, nitrogen dioxide, and nitric oxide analyses). The aqueous extracts were analyzed by either selective electrode or ion chromatography (IC). Organic analyses were performed using cryogenic preconcentration followed by gas chromatography/mass spectrometry (GC/MS).

(a) Pacific Northwest Laboratory is operated for the U. S. Department of Energy by Battelle Memorial Institute under Contract DE-AC06-76RLO 1830.

(b) PNL-TVP-07, Rev. 0, October 1994, Sample Shipping and Receiving Procedure for PNL Waste Tank Samples, PNLTechnical Procedure, Tank Vapor Project, Richland, Washington. 


\section{VAP EY 110 \\ Tivestirghouse}

\section{Hanford Company}

Custody Form initiator

Company Contact

R. D. Mahon-WHC

Project Designation/Sampling Locations 200 East Tank Farm

241-6Y-110 Tank

Vapor Sample SAF $\$ 4082$

(VSS Truck)

Ice Chest No.

Bill of Lading/Airbill No.

$N / A$

Method of Shipment

Government Truck

Shipped to

FivL

Possible Sample Hazards/Remarks Ụniknoun al time of sampling

Teicphone (509) 373-0141

Page 85-3009 / FAX 376-0418

Telephone (509) 373-1101

Page 85-9650 / FAX 373-3193

Collection date $11-1 / 2-04$ (E) $1 / 28 /$ of

Preparation dale $11-0 \quad 7-94$

Fie!d Logboox No. WHC-

Orfsile Propery No. N/A

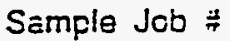

Samole Icentiñcation

$$
\begin{aligned}
& S 4082-A 25.82 V W \\
& S 4032-A 27.83 V \\
& S 4082-A 2 B .84 W \\
& S 4082-A 29.85 V \\
& S 4082-A 30.86 V \\
& S 4082-A 31.87 V \\
& S 4082-A 32.88 W \\
& S 4082-A 33.89 V \\
& S 4082-A 34.90 V
\end{aligned}
$$

\begin{tabular}{|c|c|}
\hline 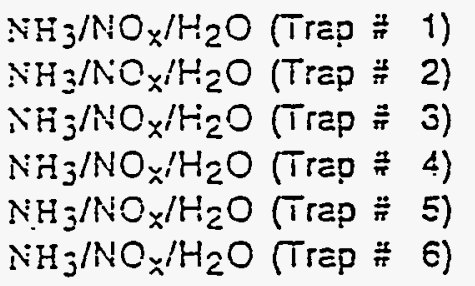 & 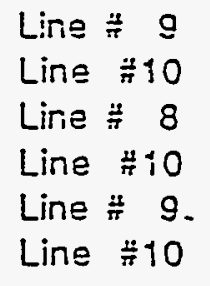 \\
\hline$y / H=0$ a-b & lank \\
\hline
\end{tabular}

\begin{tabular}{|c|c|c|c|c|c|}
\hline I I Field Transfer of Custody & & I Chair & of Possession & nd Print Name & \\
\hline Relinquished By & Deite & Time & Received By & Date & Time \\
\hline Gary Dennis M.w & $11-00-04$ & 0800 & J.A. Edwards alffeluzall & $11-00-94$ & $884 \sigma$ \\
\hline 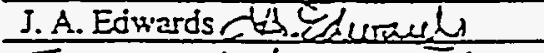 & $11+094$ & 1400 & 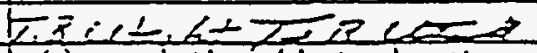 & $11+594$ & $/ 4 \infty$ \\
\hline 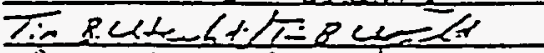 & $14-r<-54$ & 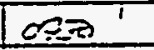 & (1) a. atilum/R.A.w2s then & $|1-1|-\{4$ & 2930 \\
\hline 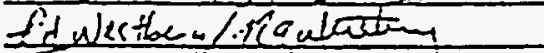 & $11-11-44$ & 1530 & 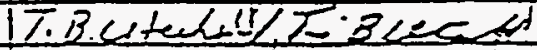 & $\angle 1-\angle E S 4$ & 153 \\
\hline 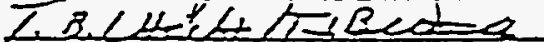 & $11-285$ & 220 & 1,4 Eounnes/ fisle & $61-28-94$ & 1200 \\
\hline IAEocumros tat Elueudo & $11-28-99$ & 1350 & Gw & $11.30-94$ & 1350 \\
\hline G.W.0emnis / F.w.L & $12-7-94$ & 1310 & TCan 2 rast & $112-7-94$ & 1310 \\
\hline
\end{tabular}

Figure 1.1a Chain-of-Custody for Inorganic Samples 


\begin{tabular}{l|cc}
\hline $\begin{array}{l}\text { Westinghouse } \\
\text { Hanford Company }\end{array}$ & CHAIN OF CUSTODY $\cdot$ & WHC 008081 \\
\hline
\end{tabular}

Custody Form Initiator

Company Contact

A. D. Mahon-WHC

Project Designation/Sampling Locations 200 East Tank Farm

241-BY-110 Tank

Vapor Sample SAF S4082

(VSS Truck)

Ice Chest No.

Bill of Lading/Airbill No.

N/A

Method of Shipment

Government Truck

Shipped 10

FNL
Telephone

Page 85-3009 / FAX 376-0418

Telephone (509) 373-1101

Page - 85-9656 / FAX 373-3193

Collection date

Preparation viate

11.11 .94 (1) $128 / 94$ $11 . \overline{0} \quad \overline{9}-94$

Field Logbook No. WHC.

Offsite Propery No. N/A

Possible Sample Hazards/Remarks Unknown at time of sampling

Sample Job $\stackrel{3}{7}$

Samole Identification

$$
\begin{aligned}
& S 4082-A 26.82 W \\
& S 4082-\wedge 27.83 W \\
& S 4082-A 28.84 V \backslash \\
& S 4082-\wedge 29.85 V \\
& S 4082-A 30.86 V \\
& S 4082-\wedge 31.87 V
\end{aligned}
$$

$\mathrm{H}_{2} \mathrm{O}-($ ) (Trap
$\mathrm{H}_{2} \mathrm{O}-(f)$ (Trap $\#$
$\mathrm{H}_{2} \mathrm{O}-(\mathrm{f})$ (Trap \#
$\mathrm{H}_{2} \mathrm{O}-(\mathrm{f})$ (Trap $\#$
$\mathrm{H}_{2} \mathrm{O}-(f)$ (Trap $\#$
$\mathrm{H}_{2} \mathrm{O}-(\mathrm{f})$ (Trap \#

1)

2)

3)

4)

5)

6)
Lin $€ \ddot{\Xi} \mathrm{Q}$

Line $\because 10$

Line $\frac{\ddot{*}}{\mathrm{i}} \quad \mathrm{a}$

Line $\# 10$

Line $\#$ o

Line $\approx 10$

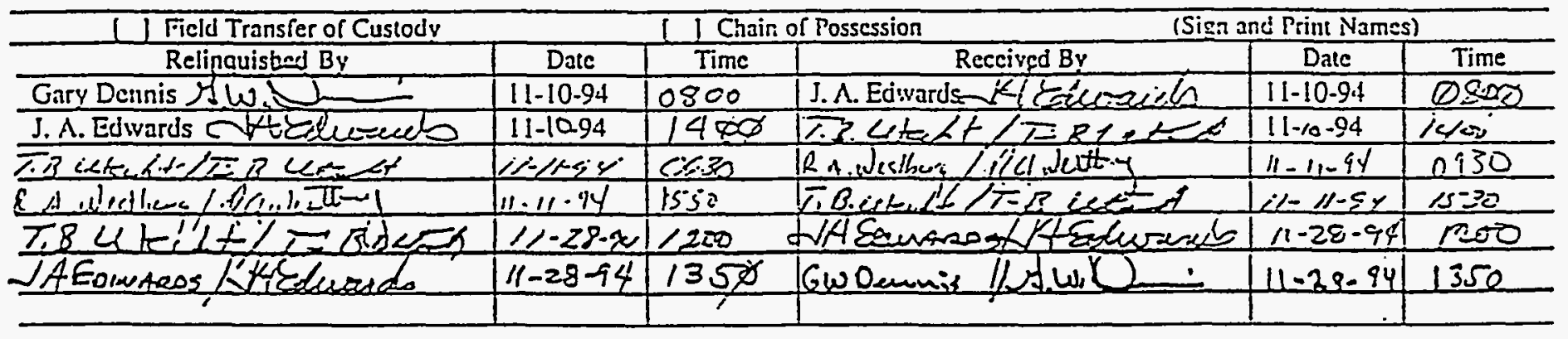

Figure 1.1b Chain-of-Custody for Inorganic Samples 


\section{Westinghouse \\ Hanford Company}

Custody Form Initiator

Company Contact

R. D. Mahon-WHC

,

Project Designation/Sampling Locations 200 East Tank Farm 241-BY-110 Tank

Vapor Sample SAF S4082

(VSS Truck)

Ice Chest No.

Bill of Lading/Airbill No.

$N / A$

Mathod of Shipment

Government Truck

Shipped to

FNL
(509) 373-0141

Telephone

Page 85-3009 / FAX 376-0418

Telephone

(509) 373.1101

Page 85-9656/FAX 373-3193

Collection date

11- $/ 1=94$ 11-29-94

Preparation date

11.10 .94

Field Logbook No. WHC-

Offsite Property No. N/A

Sample Job $\#$

Possible Sample Hazards/Remarixs Unknown at time of sampling

$S 4082-101.147^{-}$
$S 4082-A 02.148^{2}$

S4082-A07.149,

S4082-A08.150,

S4082-A09.15N
Ambicnt Air

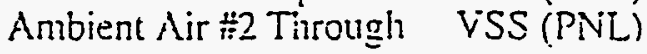

Sample $\frac{*}{\pi 6}$ (PNiL)

Sample

Sample $\ddot{\pi}$ (PNiL)

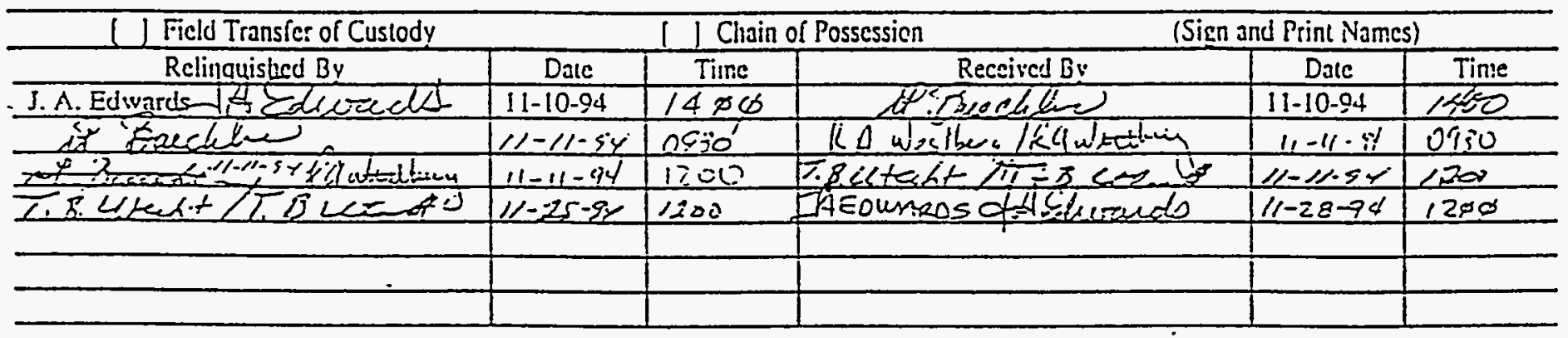

Figure 1.1c Chain-of-Custody for. Organic Samples 


\subsection{Inorganic Task}

Solid sorbent traps, prepared in multi-trap sampling trains, were supplied to WHC for sampling the tank headspace using the VSS. Blanks, spiked blanks (when requested), and exposed samples were returned to PNL for analysis. Analyses were performed to provide information on the tank-headspace concentration of the following analytes: ammonia $\left(\mathrm{NH}_{3}\right)$, nitrogen dioxide $\left(\mathrm{NO}_{2}\right)$, nitric oxide (NO), and water $\left(\mathrm{H}_{2} \mathrm{O}\right)$. Procedures were similar to those developed previously during sample jobs performed with the VSS connected to the headspace of Tank C-103 (Ligotke et al. 1994). During those sample jobs, control samples provided validation that samples were effectively trapping $\mathrm{NH}_{3}$ and mass. Sample preparation, handling, and disassembly were performed as described in Technical Procedure PNL-TVP-09(a). Analytical accuracy was estimated based on procedures used. Sample preparation and analyses were performed following PNL quality assurance (QA) impact level (IL) II requirements.

\subsection{Standard Sampling Methodology}

Standard glass tubes containing sorbent materials to trap vapors of selected analytes of $\mathrm{NH}_{3}$, $\mathrm{NO}_{2}$, NO, and $\mathrm{H}_{2} \mathrm{O}$ (SKC Inc., Eighty Four, Pennsylvania) were obtained, prepared, and submitted for use by WHC. The sorbent traps were selected based on their use by the Occupational Safety and Health Administration (OSHA) to perform workplace monitoring, and because of available procedures and verification results associated with that particular application. The typical sorbent traps used consisted of a glass tube containing a sorbent material specific to the compound of interest. In general, the tubes contained two sorbent layers, or sections; the first layer was the primary trap, and the second layer provided an indication of breakthrough. In the tubes, sorbent layers are generally held in packed layers separated by glass wool. The sorbent tubes, having glass-sealed ends, were received from the vendor.

The type and nominal quantity of sorbent material varied by application. Sorbent traps were selected for the tank sample job and included the following products. The $\mathrm{NH}_{3}$ sorbent traps contained carbon beads impregnated with sulfuric acid; nominally, $500 \mathrm{mg}$ were contained in the primary and $250 \mathrm{mg}$ in the breakthrough sections. The $\mathrm{NH}_{3}$ was chemisorbed as ammonium sulfate $\left\{\left(\mathrm{NH}_{4}\right)_{2} \mathrm{SO}_{4}\right\}$. The $\mathrm{NO}_{2}$ traps contained a zeolite impregnated with triethanolamine (TEA), with $400 \mathrm{mg}$ in the primary and $200 \mathrm{mg}$ in the breakthrough sections. The $\mathrm{NO}_{2}$ was absorbed and disproportionated to equi-molar quantities of nitrite ions $\left(\mathrm{NO}_{2}{ }^{-}\right)$and nitrate ions $\left(\mathrm{NO}_{3}{ }^{-}\right)$. Glass tubes containing $800 \mathrm{mg}$ of an oxidant such as chromate were used to convert $\mathrm{NO}$ to $\mathrm{NO}_{2}$. The converted $\mathrm{NO}$ was then collected as nitrite and nitrate in an $\mathrm{NO}_{2}$ trap. The water traps contained $300 \mathrm{mg}$ of silica gel in the primary and $150 \mathrm{mg}$ in the breakthrough sections.

Samples provided by PNL to trap inorganic compounds include all or some of the following: samples, spiked samples, spares, single trap blanks, and spiked blanks. The samples of each were prepared from same-lot batches, with the oxidizer sections of the $\mathrm{NO}_{\mathrm{x}}$ sorbent trains having been stored previously in a freezer. After sample preparation, all samples, spiked samples, blanks, and spiked blanks were stored in a freezer, primarily because of handling recommendations for the

(a) Pacific Northwest Laboratory. 10/94. Sorbent Trap Preparation for sampling and Analysis: Waste Tank Inorganic Vapor Samples, PNL-TVP-09 (Rev.0), PNL Technical Procedure, Richland, Washington. 
oxidizer tubes attached to some samples. After receipt of exposed and radiologically cleared samples from WHC and disassembly of the sorbent trains, samples were provided to the analytical laboratory at ambient temperature, and selected oxidizer sections were returned to a freezer until completion of analyses.

The sorbent traps were prepared in multi-trap sorbent trains configured so sample flow passed in order through the traps, targeting specific analytes, and then through a desiccant trap. The specific order of traps within the various sorbent trains is described in Section 2.4. The ends of the glass-tube traps were broken, and the traps were weighed and then connected to each other using uniform lengths of 3/8-in. perfluoroalkoxy (PFA)-grade Teflon ${ }^{\circledR}$ tubing. The tubing was heated in hot air and forced over the open ends of the traps to form a tight seal. The inlets of the sorbent trains each consist of a short section of tubing having a 3/8-in. stainless steel Swagelok ${ }^{\text {m }}$ nut, sealed using a Swagelok ${ }^{\circledast}$ cap. The trailing ends of the sorbent trains (the downstream end of the traps containing silica gel) were each sealed with red-plastic end caps provided by the manufacturer. The sorbent-tube trains remained sealed other than during the actual sampling periods. C-Flex ${ }^{3}$ tubing was provided by WHC to connect the downstream ends of the sorbent trains to the sampling exhaust manifold connections.

2.1.1 Concentration Calculations. The concentrations of target compounds in the tank headspace were determined from sample results, assuming effective sample transport to the sorbent traps. Concentration, in parts per million by volume (ppmv), was determined by dividing the mass of the compound, in $\mu \mathrm{mol}$, by the volume of the dried tank air sampled in mol. The micromolar sample mass was determined by dividing the compound mass, in $\mu \mathrm{g}$, by the molecular weight of the compound, in $\mathrm{g} / \mathrm{mol}$. The molar sample volume was determined, excluding water vapor, by dividing the standard sample volume (at $0^{\circ} \mathrm{C}$ and 760 torr), in $\mathrm{L}$, by $22.4 \mathrm{~L} / \mathrm{mol}$. For example, the concentration $\left(\mathrm{C}_{\mathrm{v}}\right)$ of a 3.00- $\mathrm{L}$ sample containing $75.0 \mu \mathrm{g}$ of $\mathrm{NH}_{3}$ equals

$$
\mathrm{C}_{\mathrm{v}}=\frac{75.0 \mu \mathrm{g}}{17 \mathrm{~g} / \mathrm{mol}}\left(\frac{3.00 \mathrm{~L}}{22.4 \mathrm{~L} / \mathrm{mol}}\right)^{-1}=32.9 \mathrm{ppmv}
$$

This calculational method produces concentration results that are slightly conservative (greater than actual) because the volume of water vapor in the sample stream is neglected. The volume of water vapor is not included in the measured sampled volume because of its removal in desiccant traps upstream of the mass flowmeter. However, the bias is generally expected to be small. For a tankheadspace temperature of $35^{\circ} \mathrm{C}$, the magnitude of the bias would be about 1 to $6 \%$, assuming tankheadspace relative humidities of 20 to $100 \%$, respectively. The concentration of mass (determined gravimetrically) was also per dry-gas volume at standard conditions.

\subsection{Analytical Procedures}

The compounds of interest were trapped using solid sorbents and chemisorption (adsorption of water vapor). Analytical results were based on extraction and analysis of selected ions. Analytical procedures used are specified in the text. All were compiled in PNL-MA-599.

2.2.1 Ammonia Analysis. The sorbent material from the $\mathrm{NH}_{3}$-selective sorbent traps was placed into labeled $20-\mathrm{mL}$ glass scintillation vials. Vials containing front-, or primary-, section sorbent 
material were treated with $10.0 \mathrm{~mL}$ of deionized water (DIW), and vials containing back-up-section sorbent material were treated with $5.0 \mathrm{~mL}$ of DIW. After extraction, the $\mathrm{NH}_{3}$ sorbent traps were analyzed using the selective ion electrode (SIE) procedure PNL-ALO-226 \{Ammonia (Nitrogen) in Aqueous Samples\}. Briefly, this method includes 1) preparing a $1000-\mu \mathrm{g} / \mathrm{mL}$ (ppm) $\mathrm{NH}_{3}$ stock standard solution from dried reagent-grade $\mathrm{NH}_{4} \mathrm{Cl}$ and $\mathrm{DIW}$ on the day analyses are performed; 2) preparing $0.1-, 0.5-, 1.0-, 10-$, and $100-\mathrm{ppm} \mathrm{NH}_{3}$ working calibration standards by serial dilution of the freshly made stock standard; 3 ) generating an initial calibration curve from the measured electromotive force (emf) signal versus $\mathrm{NH}_{2}$ concentration data obtained for the set of working standards; 4) performing a calibration-verification check, using one of the midrange standards, after analyzing every four or five samples; 5) continuing this sequence until all samples of the batch have been measured, including duplicates and spiked samples; and 6) remeasuring the complete set of calibration standards (at the end of the session). Emf signal measurements obtained for samples are compared to those for standards, either graphically or algebraically (using linear regression) to determine $\mathrm{NH}_{3}$ concentration in the samples.

2.2.2 Nitrite Analysis. The sorbent traps for $\mathrm{NO}_{2}$ and $\mathrm{NO}$ were desorbed in an aqueous TEA and n-butanol solution and analyzed by suppressed-conductivity ion chromatography (SCIC) for nitrite according to PNL-ALO-212, Rev. 1 (Determination of Inorganic Anions by Ion Chromatography) modified to obviate interferences by concentrations of non-target analytes. Specifically, the modifications used were 1) eluent $1.44 \mathrm{mM} \mathrm{Na}_{2} \mathrm{CO}_{3}+1.8 \mathrm{mM} \mathrm{NaHCO}_{3}$ at $2.0 \mathrm{~mL} / \mathrm{min}$, 2) one guard column (AG4A) and two separator columns (AS4A) in series instead of just one separator column, and 3) all standards, samples, and blanks injected into the IC sample loop through $0.45-\mu \mathrm{m}$ syringe filters.

For the analysis, the sorbent materials were placed into labeled 20 -mL glass scintillation vials. To each vial, $3.0 \mathrm{~mL}$ of desorbing solution (15 g.TEA $+1 \mathrm{~mL}$-butanol in $1.0 \mathrm{~L} \mathrm{DIW}$ ) was added. Primary sorbent-tube sample materials and back-up (breakthrough) sorbent-trap materials were analyzed separately using identical procedures. Each analytical session was conducted as follows. Working nitrite standards $(0,0.1,0.25$, and $0.5 \mathrm{ppm})$ were prepared by diluting a stock nitrite standard with desorbing solution. An initial calibration curve was prepared from the instrument response (chromatographic peak height) versus nitrite standard concentration data for the set of working standards. A calibration verification check using one of the midrange standards was performed after the analysis of every six samples. If the instrument response indicated that sample nitrite concentration was outside the calibration range ( $>0.5 \mathrm{ppm}$ nitrite), the sample was diluted with desorbing solution and reanalyzed. After all samples of a batch were analyzed, the complete set of calibration standards was remeasured to verify consistent instrument response, and the analytical session was terminated.

Instrument responses (peak height) observed for samples were compared to those for standards to determine the nitrite concentration of the samples. Because $\mathrm{NO}_{2}$ and $\mathrm{NO}$ converted to $\mathrm{NO}_{2}$ were collected on the sorbent as equal quantities of nitrite and nitrate, and the analysis was specific for nitrite, the molar masses of $\mathrm{NO}_{2}$ and $\mathrm{NO}$ were determined by doubling the analytically determined molar mass of nitrite.

2.2.3 Mass (Water) Analysis. Sorbent traps used to make each sample train were weighed using a semi-micro mass balance, after labeling and breaking the glass tube ends, without plastic end caps. After receipt of exposed samples, the sorbent traps were again weighed to determine the change in mass. Records of the measurements were documented on sample-preparation data sheets. The mass 
concentration, generally roughly equal to the concentration of water, was determined by dividing the combined change in mass from all traps in a sorbent train by the actual volume of gas sampled. Blanks and spiked blanks were included to provide information on uncertainty.

\subsection{Quality Assurance/Quality Control}

Analytical work was performed according to quality levels identified in the project QA plan and several PNL documents. The samples were analyzed following PNL IL II. The PNL documents include PNL-TVP-07, PNL-TVP-09, PNL-MA-70 (Part 2), PNL-MA-599, PNL-ALO-212, PNL-ALO-226, and PNL-ALO-271. A summary of the analysis procedures and limits for the target inorganic compounds is provided in Table 2.1. From the table, it can be seen that the minimum detection limit (MDL) required to resolve the analyte at one-tenth of the recommended exposure limit (REL) for each of the target analytes is achieved using current procedures and with a vapor-sample volume of $3 \mathrm{~L}$ and a desorption-solution volume of $3 \mathrm{~mL}\left(10 \mathrm{~mL}\right.$ for $\left.\mathrm{NH}_{3}\right)$.

Table 2.1. Analysis Procedures and Typical Detection Limits of Target Inorganic Analytes. Not all analytes are included in every sample job.

\begin{tabular}{|c|c|c|c|c|c|}
\hline Analyte & Formula & Procedure & $\begin{array}{l}\mathrm{REL}^{(\mathrm{a})} \\
\text { (ppmv) }\end{array}$ & $\begin{array}{c}0.1 \times R^{\prime} L^{(2)} \\
\text { (ppmV) }\end{array}$ & $\begin{array}{l}\mathrm{MDL}^{(b)} \\
\text { (ppmv) }\end{array}$ \\
\hline Ammonia & $\mathrm{NH}_{3}$ & PNL-ALO-226 & 25 & 2.5 & 0.5 \\
\hline Nitrogen Dioxide & $\mathrm{NO}_{2}$ & PNL-ALO-212 & 1 & 0.1 & 0.02 \\
\hline Nitric oxide & NO & PNL-ALO-212 & 25 & 2.5 & 0.02 \\
\hline Mass (water) ${ }^{(\mathfrak{c})}$ & $\mathrm{n} / \mathrm{a}$ & $\mathrm{n} / \mathrm{a}$ & $\mathrm{n} / \mathrm{a}$ & $\mathrm{n} / \mathrm{a}$ & $\mathrm{n} / \mathrm{a}$ \\
\hline
\end{tabular}

(a) Target analytical limits are equal to one-tenth of the REL.

(b) MDL is defined as the vapor concentration that can be detected with an uncertainty equal to about the magnitude of the measurement. The uncertainty is expected to reduce to about one-quarter of the magnitude of the measurement at a concentration of four times the MDL. The MDLs were based on the assumption that $3 \mathrm{~L}$ of vapor are sampled; if greater volumes of vapor are sampled, correspondingly smaller MDLs can be achieved. The MDLs were also based on desorbing-solution volumes of $10 \mathrm{~mL}$ for $\mathrm{NH}_{3}$ and $3 \mathrm{~mL}$ for the other analytes.

(c) The vapor-mass concentration, thought to be largely water vapor, is determined gravimetrically.

The accuracy of concentration measurements depends on errors associated with both sampling and analysis (see Section 2.4.1). Sampling information, including sample volumes was provided by WHC; sample volume uncertainty was not provided. The accuracy of analytical results depends on the method used. For $\mathrm{NH}_{3}$ analyses, the accuracy of laboratory measurements by SIE was estimated to be $\pm 5 \%$ relative, independent of concentration at $1 \mu \mathrm{g} / \mathrm{mL}$ or greater levels. The uncertainty includes preparation of standards, purity of the ammonium salt used to prepare standards, potential operator bias, ambient temperature variations, etc. Unfortunately, no known National Institute for Standards and Technology (NIST)-traceable standard reference material (SRM) is available against which to compare working standards. Similarly, no known NIST SRM is available for nitrite analysis (for $\mathrm{NO}_{2}$ and $\mathrm{NO}$ ). Based on experience in comparing nitrite working standards prepared from several different sources and factors mentioned for $\mathrm{NH}_{3}$ above, the estimated maximum bias for 
samples derived from sampling for $\mathrm{NO}_{2}$ is $\pm 10 \%$, and for samples derived from sampling for $\mathrm{NO}$, it is $\pm 5 \%$ relative.

The accuracy of measurements of sample mass is $\pm 0.05 \mathrm{mg}$, or much less than $1 \%$ of the mass changes of most samples, and roughly $10 \%$ or less of the mass change of most blanks. The analytical accuracy of measurements of the change in mass of sorbent trains is estimated to be $\pm 1 \mathrm{mg}$ per 5-trap sorbent train; this estimate is based largely on preliminary information that unopened field-blank sorbent trains gain $0.3 \pm 0.4 \mathrm{mg}$ per train.

\subsection{Inorganic Sample Results}

Samples were obtained by WHC from the headspace of Tank BY-110 on 11/11/94 using the VSS. The sample job designation number was S4082. Samples were prepared, submitted to WHC, and then analyzed to provide information on the concentrations of $\mathrm{NH}_{3}, \mathrm{NO}_{2}, \mathrm{NO}$, and $\mathrm{H}_{2} \mathrm{O}$.

Sampling and analysis for hydrogen cyanide $(\mathrm{HCN})$ and sulfur oxides $\left(\mathrm{SO}_{x}\right)$ were not requested. The inorganic samples were received from WHC on 11/28/94; the sample-volume information was received on $12 / 6 / 94$.

A list of samples, sampling information, sample volumes, and gravimetric results is shown in Table 2.2. The types of sample trains used and the order of sorbent traps within each train are also shown in the table. For example, the sorbent train $\mathrm{NH}_{3} / \mathrm{NO}_{x} / \mathrm{H}_{2} \mathrm{O}$ contained an $\mathrm{NH}_{3}$ trap at the inlet end, an $\mathrm{NO}_{x}$ series in the middle (Section 2.4.2), and a desiccant trap at the outlet end. Analytical mass and concentration results are shown in Table 2.3. Sample volumes were provided by WHC; sample-volume uncertainty was not provided. Tank-headspace concentration results (Table 2.3) are based on this information, and the listed uncertainties equal plus-or-minus one standard deviation of the individual results from each set of samples. Where analytical results from samples were nearly indistinguishable from those of blanks, indicating very low vapor concentrations of the analyte, the concentration results (Table 2.3) are listed as "less than or equal to" a probable maximum value determined by subtracting the average of the blanks less one standard deviation from the average of the samples plus one standard deviation. Results of control samples, such as spiked blanks, are discussed in this section. Spiked blanks, when used, were transported to the field but not opened. Spiked samples, when used, were opened in the field and used to collect tank vapors. Sample results were not corrected for the percentage recoveries of spiked blanks.

2.4.1 Ammonia Results. The concentration of $\mathrm{NH}_{3}$ was $401 \pm 15 \mathrm{ppmv}$, based on all six samples. The blank-corrected $\mathrm{NH}_{3}$ quantities in the sorbent traps ranged from 52 to $57 \mu \mathrm{mol}$ in the front sorbent sections and were about $0.03 \mu \mathrm{mol}$ in back sorbent sections. Blank corrections, $\leq 0.06 \mu \mathrm{mol}$ in front and back sections, were less than $0.1 \%$ of collected quantities and were neglected. Although spiked blanks were not tested, the percentage recoveries of three sets of blanks spiked with 12.2, 22.3 , and $46.4 \mu \mathrm{mol}$ of $\mathrm{NH}_{3}$ were $101 \pm 4 \%, 109 \pm 2 \%$, and $104 \pm 1 \%$, respectively, during related sample jobs (Clauss et al. 1994; Ligotke et al. 1994). The analysis of one sample was duplicated and yielded a repeatability of $\pm 4 \%$. No sample leachates were spiked after initial analysis to test percentage recovery. A 5-point calibration was performed over an $\mathrm{NH}_{3}$ range of 0.1 to $1000 \mu \mathrm{g} / \mathrm{mL}$. 
Table 2.2 List of PNL Inorganic Samples, Controls, and Gravimetric Results Obtained From a Heated Tube Inserted into the Headspace of Tank BY-110 on 11/11/94

\begin{tabular}{|c|c|c|c|c|c|c|}
\hline \multirow[b]{2}{*}{ Sample Number } & \multirow[b]{2}{*}{ Sorbent Type } & \multirow[b]{2}{*}{$\begin{array}{c}\text { Sample } \\
\text { Port } \\
\end{array}$} & \multicolumn{3}{|c|}{ Sample Port and Volume Information ${ }^{(2)}$} & \multirow[b]{2}{*}{$\begin{array}{c}\text { Mass } \\
\text { Gain (g) }\end{array}$} \\
\hline & & & $\begin{array}{l}\text { Flow Rate } \\
(\mathrm{mL} / \mathrm{min})\end{array}$ & $\begin{array}{c}\text { Duration } \\
\text { (min) }\end{array}$ & $\begin{array}{c}\text { Volume } \\
\text { (L) }\end{array}$ & \\
\hline Samples: & & & & & & \\
\hline$S 4082-A 26-82 V$ & $\mathrm{NH}_{3} / \mathrm{NO}_{2} / \mathrm{H}_{2} \mathrm{O}$ Train & 9 & 200 & 15.0 & 3.00 & 0.0373 \\
\hline$S 4082-A 27-83 V$ & $\mathrm{NH}_{3} / \mathrm{NO}_{2} / \mathrm{H}_{2} \mathrm{O}$ Train & 10 & 200 & 15.0 & 3.00 & 0.0279 \\
\hline$S 4082-\mathrm{A} 28-84 \mathrm{~V}$ & $\mathrm{NH}_{3} / \mathrm{NO}_{x} / \mathrm{H}_{2} \mathrm{O}$ Train & 8 & 200 & 15.0 & 3.00 & 0.0275 \\
\hline S4082-A29-85V & $\mathrm{NH}_{3} / \mathrm{NO}_{2} / \mathrm{H}_{2} \mathrm{O}$ Train & 10 & 200 & 15.0 & 3.00 & 0.0264 \\
\hline S4082-A30-86V & $\mathrm{NH}_{3} / \mathrm{NO}_{\mathbf{v}} / \mathrm{H}_{2} \mathrm{O}$ Train & 9 & 200 & 15.0 & 3.00 & 0.0267 \\
\hline S4082-A31-87V & $\mathrm{NH}_{3} / \mathrm{NO}_{1} / \mathrm{H}_{2} \mathrm{O}$ Train & 10 & 200 & 15.0 & 3.00 & 0.0272 \\
\hline$S 4082-A 32-88 V$ & $\mathrm{NH}_{3} / \mathrm{NO}_{x} / \mathrm{H}_{2} \mathrm{O}$ Blanks & $n / a^{(b)}$ & $n / a$ & $\mathrm{n} / \mathrm{a}$ & $\mathrm{n} / \mathrm{a}$ & 0.0009 \\
\hline S4082-A33-89V & $\mathrm{NH}_{3} / \mathrm{NO}_{2} / \mathrm{H}_{2} \mathrm{O}$ Blanks & $\mathbf{n} / \mathbf{a}$ & $n / a$ & $\mathbf{n} / \mathbf{a}$ & $\mathrm{n} / \mathrm{a}$ & 0.0005 \\
\hline S4082-A34-90V & $\mathrm{NH}_{3} / \mathrm{NO}_{\checkmark} / \mathrm{H}_{2} \mathrm{O}$ Blanks & $\mathrm{n} / \mathrm{a}$ & n/a & na & $n / a$ & 0.0005 \\
\hline
\end{tabular}

(a) Sampling information and dry-gas sample volumes, corrected to $0^{\circ} \mathrm{C}$ and 760 torr, were provided by WHC. Uncertainty values were not provided with sample-volume results.

2.4.2 Nitrogen Oxides Results. Measurements of $\mathrm{NO}_{2}$ and $\mathrm{NO}$ were made using six 5-segment $\mathrm{NH}_{3} / \mathrm{NO}_{\mathrm{x}} / \mathrm{H}_{2} \mathrm{O}$ sorbent-trap trains (the $\mathrm{NO}_{\mathrm{x}}$ trains consisted of $\mathrm{NO}_{2}$ trap, oxidizer, and $\mathrm{NO}_{2}$ trap). Related sample jobs, performed using the VSS in Tanks BY-104, -105 , and -106 both with and without $\mathrm{NO}_{\mathrm{x}}$ trains protected by a leading $\mathrm{NH}_{3}$ trap (e.g., Clauss et al. 1994), indicated that the presence of the upstream $\mathrm{NH}_{3}$ traps resulted in $\mathrm{NO}$ concentrations that were about 1.3- to 1.6-fold less than those from unprotected $\mathrm{NO}_{2}$ traps. The $\mathrm{NO}_{2}$ concentrations were also potentially less following an $\mathrm{NH}_{3}$ trap.

The concentrations of $\mathrm{NO}_{2}$ and $\mathrm{NO}$ were $\leq 0.05$ and $\leq 0.09$ ppmv, respectively. Blankcorrected $\mathrm{NO}_{2}{ }^{-}$quantities in the sorbent traps averaged $\leq 0.0036 \mu \mathrm{mol}\left(\mathrm{NO}_{2}\right.$ samples) and $\leq 0.0063 \mu \mathrm{mol}$ (NO samples). Nitrite blank levels used to correct data were $0.0129 \pm 0.0014 \mu \mathrm{mol}$ in front (three of six blanks analyzed) and $0.0077 \pm 0.0002 \mu \mathrm{mol}$ in back (one of six blanks analyzed) sorbent sections. Although spiked blanks were not tested, blanks spiked with 0.0064 , $0.047,0.11$, and $0.74 \mu \mathrm{mol}$ of $\mathrm{NO}_{2}^{-}$during related sample jobs yielded percentage recoveries of $153 \pm 14 \%, 103 \pm 4 \%, 106 \pm 8 \%$, and $111 \pm 7 \%$, respectively (Clauss et al. 1994; Ligotke et al. 1994). The analysis of two samples were duplicated and yielded a repeatabilities of \pm 1 and $\pm 5 \%$. Two sample leachates and one blank were spiked with $0.25 \mathrm{ppm} \mathrm{NO}_{2}{ }^{-}$and yielded a percentage recoveries of 99,101 , and $102 \%$. A 4-point calibration was performed over a concentration range of 0 to $0.5 \mu \mathrm{g} \mathrm{NO}_{2}^{-}$per $\mathrm{mL}$ in the desorbing matrix.

2.4.3 Gravimetric Results. The mass concentration of material collected in the 5-trap sorbent trains, believed to be primarily water vapor, was $9.2 \pm 0.2 \mathrm{mg} / \mathrm{L}$. The result was based on an average mass gain of $27.4 \mathrm{mg}$ from five of six $\mathrm{NH}_{3} / \mathrm{NO}_{2} / \mathrm{H}_{2} \mathrm{O}$ sample trains. The first sample yielded a significantly greater than average mass concentration of $12.5 \mathrm{mg} / \mathrm{L}$ and was neglected. The blank correction applied to the results was $0.3 \mathrm{mg}$ per sample train, based on mass loss of $0.3 \pm 0.4 \mathrm{mg}$ 
Table 2.3 Inorganic Vapor Sample Results Obtained From a Heated Tube Inserted into the Headspace of Tank BY-110 on 11/11/94

Analytical Results ( $\mu \mathrm{mol})$

Sample

$\mathrm{NH}_{3}$ Samples:

S4082- A26-82V

S4082- A27-83V

S4082- A28-84V

S4082- A29-85V

S4082- A30-86V

S4082- A31-87V

NO, Samples:

S4082- A26-82V

S4082- A27-83V

S4082- A28-84V

S4082- A29-85V

S4082- A30-86V

S4082- A31-87V

NO Samples:

S4082- A26-82V

S4082- A27-83V

S4082- A28-84V

S4082- A29-85V

S4082- A30-86V

S4082- A31-87V

Gravimetric Samples (mg.mo/L):

S4082- A26-82V

S4082- A27-83V

S4082- A28-84V

S4082- A29-85V

S4082- A30-86V

S4082- A31-87V

\begin{tabular}{|c|c|c|c|c|}
\hline \multirow[t]{2}{*}{$\begin{array}{c}\text { Front } \\
\text { Section }\end{array}$} & \multirow[t]{2}{*}{$\begin{array}{c}\text { Back } \\
\text { Section }\end{array}$} & \multirow{2}{*}{$\begin{array}{c}\begin{array}{c}\text { Total }^{(0)} \\
\text { Blank-Corrected }\end{array} \\
\underline{53.8^{(())}}\end{array}$} & \multirow{2}{*}{$\begin{array}{c}\begin{array}{c}\text { Sample } \\
\text { Volume } \\
(\mathrm{L})\end{array} \\
{\underline{3.00^{(\mathrm{e})}}}\end{array}$} & \multirow{2}{*}{$\begin{array}{c}\begin{array}{c}\text { Vapor }^{(\mathrm{a})} \\
\text { Concentration } \\
\text { (ppmv) }\end{array} \\
\underline{401 \pm \underline{15}^{(\mathrm{)})}}\end{array}$} \\
\hline & & & & \\
\hline 57.1 & 0.03 & 57.1 & 3.00 & 426 \\
\hline 54.7 & 0.03 & 54.7 & 3.00 & 408 \\
\hline 51.6 & 0.03 & 51.6 & 3.00 & 385 \\
\hline 52.2 & 0.06 & 52.2 & 3.00 & 390 \\
\hline 53.6 & 0.03 & 53.6 & 3.00 & 400 \\
\hline \multirow[t]{2}{*}{53.4} & 0.06 & 53.4 & 3.00 & 399 \\
\hline & & $\leq 0.0036$ & 3.00 & $\leq 0.05$ \\
\hline 0.0135 & $N A^{(d)}$ & $\pi / a$ & 3.00 & $n / a$ \\
\hline 0.0158 & NA & $n / a$ & 3.00 & $\mathrm{n} / \mathrm{a}$ \\
\hline 0.0129 & 0.0076 & $n / a$ & 3.00 & $n / a$ \\
\hline 0.0147 & NA & $\pi / a$ & 3.00 & $\mathrm{n} / \mathrm{a}$ \\
\hline 0.0140 & NA & $n / a$ & 3.00 & $\mathrm{n} / \mathrm{a}$ \\
\hline \multirow[t]{2}{*}{0.0132} & NA & $\mathrm{n} / \mathrm{a}$ & 3.00 & $\mathrm{n} / \mathrm{a}$ \\
\hline & & $\underline{0.0063}$ & $\underline{3.00}$ & $\leq 0.09$ \\
\hline 0.0175 & NA & $\mathbf{n} / \mathbf{a}$ & 3.00 & $n / a$ \\
\hline 0.0174 & $\mathrm{NA}$ & $\mathrm{n} / \mathrm{a}$ & 3.00 & $\mathrm{n} / \mathrm{a}$ \\
\hline 0.0180 & $\mathrm{NA}$ & $\pi / 2$ & 3.00 & $\mathrm{n} / \mathrm{a}$ \\
\hline 0.0175 & NA & $n / a$ & 3.00 & $n / a$ \\
\hline 0.0172 & $\mathrm{NA}$ & $\mathrm{n} / \mathrm{a}$ & 3.00 & $n / a$ \\
\hline \multirow[t]{2}{*}{0.0173} & 0.0079 & $\mathrm{n} / \mathrm{a}$ & 3.00 & $\mathrm{n} / \mathrm{a}$ \\
\hline & & $27.4 \mathrm{mg}$ & 3.20 & 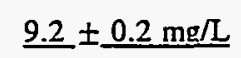 \\
\hline$n / a$ & n/a & $37.6 x^{(d)}$ & 3.00 & $12.5 x^{(d)}$ \\
\hline$n / a$ & $n / a$ & 28.2 & 3.00 & 9.4 \\
\hline$n / a$ & $n / a$ & 27.8 & 3.00 & 9.3 \\
\hline $\mathrm{n} / \mathrm{a}$ & $n / a$ & 26.7 & 3.00 & 8.9 \\
\hline$n / a$ & $\pi / \mathbf{a}$ & 27.0 & 3.00 & 9.0 \\
\hline$n / a$ & $n / a$ & 27.5 & 3.00 & 9.2 \\
\hline
\end{tabular}

(a) Blank-corrected vapor concentrations were calculated using WHC-reported dry-air sample volumes (corrected to $\mathrm{O}^{\circ} \mathrm{C}$ and 760 torr). In the calculation for concentration, the nitrite values (listed) were doubled to account for unanalyzed nitrate. Sample results were not corrected for percentage recovery of spiked samples or spiked blanks.

(b) Total blank-corrected analyte masses (nitrite for $\mathrm{NO}_{2}$ and $\mathrm{NO}$ ) were determined, when significant, by subtracting the quantity of analyte found in blanks from that found in samples. The level of analytes found in blanks is described in the subsections of Section 2.4 .

(c) Underlined values represent the average of the set samples. Concentration uncertainty equals \pm 1 standard deviation (absolute) for each set of samples. The use of " $\leq$ " is defined in Section 2.4.

(d) NA $=$ not analyzed; $n / a=$ not applicable; $x=$ not included in determination of average concentration. Only selected back sorbent sections were analyzed. Past results have shown back sections of $\mathrm{NH}_{3}$ samples to contain insignificant quantities of the analyte. 
per three blank 5-trap sorbent trains. The blanks, first assembled as complete 5-trap sorbent trains, accompanied samples from three related VSS sample jobs in December 1994 (TX-105, TX-118, and BX-104). Although no spiked blanks were tested, the percentage recovery of mass from three blank $\mathrm{H}_{2} \mathrm{O}$ traps spiked with $51 \mathrm{mg}$ of water was $103 \pm 2 \%$ during a related sample job (Clauss et al. 1994).

As a special control test, six additional silica-gel traps were provided along with the six sample trains. The additional traps were installed by WHC downstream of the 5-trap sample trains to test for carrythrough of vapor mass. The six additional traps gained $0.9 \pm 0.2 \mathrm{mg}$ per sample, indicating a carrythrough equal to about $3 \%$ of the mass collected in the standard 5-trap sample trains. If added to the vapor mass concentration measured using the standard 5-train traps, the vapor mass concentration would be $9.5 \mathrm{mg} / \mathrm{L}$. To maintain consistency with the standard sampling and analysis procedures, no correction was made to the results. 


\subsection{Organic Task}

\subsection{SUMMA ${ }^{T M}$ Canister Preparation}

Before sending SUMMA ${ }^{\text {xH }}$ canisters out to the field for sampling, the canisters are cleaned and verified contaminant free according to PNL Technical Procedure PNL-TVP-02 ${ }^{(a)}$. The cleaning procedure uses an EnTech 3000 cleaning system that controls 1) filling the canisters with purified humid air and 2) evacuating, for several cycles with applied heat, before allowing the canister to evacuate overnight. The canister is filled a final time with purified humid air for analysis by PNL Technical Procedure PNL-TVP-01 ${ }^{(b)}$, which is a modification of U.S. Environmental Protection Agency (EPA) compendium Method TO-14. If the canister is verified as clean, free of TO-14 and unknown contaminants to a level of 5 parts per billion by volume (ppbv), the canister is evacuated to $30 \mathrm{in} . \mathrm{Hg}$, tagged, and stored for use in the field. Before sending the canisters out to the field for sampling, the canister vacuum is measured to determine if any leakage has occurred. If the vacuum has remained constant during storage, the canisters are prehumidified with $100 \mu \mathrm{L}$ of distilled water and labeled with a field-sampling identification. Canisters stored more than 30 but less than 60 days are re-evacuated and rehumidified before use. If stored more than 60 days, the canisters are recleaned and validated before use.

\subsection{Sample Analysis Method}

The SUMMAA ${ }^{\mathrm{Tt}}$ canister sample was analyzed according to PNL Technical Procedure PNLTVP-03, Determination of TO-14 Volatile Organic Compounds in Hanford Waste Tank Headspace Samples Using SUMMA ${ }^{\text {Ta }}$ Passivated Canister Sampling and Gas Chromatographic-Mass Spectrometry Analysis, which is a modified version of EPA compendium Method TO-14. The method uses an EnTech cryoconcentration system interfaced with either a 5971 or a 5972 Hewlett Packard (HP) benchtop GC/MS. The EnTech concentrator is used to pull a metered volume of sample air from the SUMMA $^{\text {Th }}$ canister, cryogenically concentrate the air volume, then transfer the volume to the GC/MS for analysis. A $100-\mathrm{mL}$ volume of sample is measured and analyzed from the tank headspace. The organic components in the sampled air are separated on an analytical column, J\&W Scientific DB-1 phase, $60-\mathrm{m}$ by $0.32-\mathrm{mm}$ internal diameter with $3-\mu \mathrm{m}$ film thickness. The $\mathrm{GC}$ oven is programmed to run a temperature gradient beginning at $40^{\circ} \mathrm{C}$, holding for $5 \mathrm{~min}$, and ramping at $4^{\circ} \mathrm{C}$ per min to a final temperature of $260^{\circ} \mathrm{C}$, with a 5-min hold. Twenty-four hours before the analysis, the SUMMA ${ }^{\text {ns }}$ canister samples were pressurized with purified air (Aadco Instruments, Inc., 1920 Sherwood St., Clearwater, Florida 34625). The starting pressure was first measured using a calibrated diaphragm gauge (Cole Parmer) then pressurized to a level exactly twice the original pressure. For example, if the canister had a starting pressure of 740 torr, it was pressurized to 1480 torr. This dilution was an effort to improve the precision of the analysis. The sample dilution was taken into account when calculating the analysis results.

(a) Pacific Northwest Laboratory. 8/94. Cleaning SUMMA' Canisters and the Validation of the Cleaning Process, PNL-TVP-02 (Rev. 0), PNL Technical Procedure, Richland, Washington.

(b) Pacific Northwest Laboratory. 8/94. Determination of TO-14 Volatile Organic Compounds in Ambient Air Using SUMMA ${ }^{\text {Tx }}$ Passivated Canister Sampling and Gas Chromatographic-Mass Spectrometric Analysis, PNL-TVP-01 (Rev. 0). PNL Technical Procedure, Richland, Washington. 
The instrument calibration mixture for the TO-14 analysis consists of the standard 40 organic analytes with an additional 15 tank related compounds. Together, these 55 compounds that are directly quantified in the analysis make up the target analyte list. (These 55 compounds will be referred to as target analytes). The calibration mixture was prepared by blending a commercially prepared 40-compound TO-14 calibration mixture with a 15-compound mixture created using a $\mathrm{KinTech}^{\circledast}$ permeation-tube standard generation system. The operation of the permeation tube system follows the method detailed in Preparation of TO-14 Volatile Organic Compounds Gas Standards, PNL Technical Procedure PNL-TVP-06. The standard calibration mix was analyzed using six aliquot sizes ranging from $5 \mathrm{~mL}$ to $300 \mathrm{~mL}$. Depending on the concentration of each analyte in the mixture, either five or six points were used to construct the calibration curve. Butonic acid was added to the mixture, but was not detected in the analysis. Butanal was recovered very poorly, producing a much lower than expected response. This results in a much higher measured amount reported in the sample analysis. This problem is currently under investigation. Performance-based detection limits for the target analytes will be developed as a pool of calibration data becomes available. Currently, the nominal detection limit of $5 \mathrm{ppbv}$ is met.

The SUMMA ${ }^{\mathrm{TM}}$ canister samples were analyzed for permanent gases according to PNL Technical Procedure PNL-TVP-05, Analysis Method for the Determination of Permanent Gases in Hanford Waste Tank Vapor Samples Collected in SUMMA ${ }^{\mathrm{TM}}$ Passivated Stainless Steel Canisters, with the exceptions listed in the following text and in the Quality Assurance/Quality Control section of this report. This method was developed in-house for the analysis of permanent gases defined as hydrogen $\left(\mathrm{H}_{2}\right)$, carbon dioxide $\left(\mathrm{CO}_{2}\right)$, carbon monoxide $(\mathrm{CO})$, methane $\left(\mathrm{CH}_{4}\right)$, and nitrous oxide $\left(\mathrm{N}_{2} \mathrm{O}\right)$ by gas chromatography/thermal conductivity detection (GC/TCD) and is not validated in any other laboratory. No previous work up of the sample canister is necessary before permanent gas analysis. Aliquots of sampled air are manually drawn from each canister into a 5-mL gas-tight syringe and directly injected into a GC/TCD fitted with a $1.0-\mathrm{mL}$ injection loop. An aliquot of $5 \mathrm{~mL}$ is used so that the injection loop is flushed and filled with sample air, ensuring that no dilution of sample concentration takes place within the injection loop. One set of GC conditions is used to analyze for $\mathrm{CO}, \mathrm{CO}_{2}, \mathrm{~N}_{2} \mathrm{O}$, and $\mathrm{CH}_{4}$ using Helium ( $\mathrm{He}$ ) as the carrier gas. A second $\mathrm{GC}$ analysis is performed for $\mathrm{H}_{2}$ (using nitrogen as the carrier gas) to enhance the signal sensitivity and lower the detection limit for this analyte. A total of 30 to $60 \mathrm{~mL}$, depending upon the number of repeat analyses performed, may be drawn from each $6-\mathrm{L}$ canister.

\subsection{Quality Assurance/Quality Control}

Before the tank sample was analyzed, a diagnostic check was performed on the GC/MS instrument by running an instrument "quick tune," as described in PNL-TVP-03. Upon satisfactory completion of the instrument diagnostic check, a blank volume of purified nitrogen was analyzed to check the cleanliness of the system. The instrument was then calibrated over 5 to 6 data points ranging from $5 \mathrm{ppbv}$ to $300 \mathrm{ppbv}$, using a standard gas mixture containing 40 volatile organic compounds listed in EPA compendium Method TO-14 and an additional 15 tank-related compounds. A gas mixture containing bromochloromethane, 1,4-difluorobenzene, and chlorobenzene- $d_{5}$ was used as an internal standard (IS) for all blank, calibration standard, and sample analyses. Analyte responses from sample components, ISs, and standards were obtained from the extracted ion plot from their selected mass ion. The calibration curve was generated by calculating the relative response ratios of the IS to calibration standard responses and plotting the ratios against the ratio of the calibration-standard concentration (in ppbv) to the IS concentration. A least-squares linear-regression 
routine was applied to the data set to generate the best-fit line for each compound. The equation for that line was then used to quantify the target analytes found in the tank samples.

Standards for the permanent gas analysis were blended from commercially prepared and certified standards for each of the analytes reported in Table 3.5. The instrument was calibrated over three data points for $\mathrm{CO}, \mathrm{CO}_{2}, \mathrm{~N}_{2} \mathrm{O}$, and $\mathrm{CH}_{4}$ using $\mathrm{He}$ as a carrier gas, and then the samples were analyzed. The carrier was changed to $\mathrm{N}_{2}$, the calibration was performed for $\mathrm{H}_{2}$ only, and the samples were reanalyzed. A least-squares linear-regression routine was applied to the data set to generate the best fit for each compound. The quantitation for each analyte was performed by direct comparison of sample analyte peaks to the plot generated for the compound. The lowest calibration standard for each analyte is reported as the method detection limit. An MDL for the instrument has not been determined. An $\mathrm{N}_{2}$ reagent blank was not analyzed with this set of samples. The ambient air sample collected $\sim 10 \mathrm{~m}$ upwind of BY-110 and the ambient air collected through the VSS were used as method blanks and used to determine the potential for analyte interferences in the samples.

Continuing calibration standards for this sample set fell within $\pm 25 \%$ of the expected concentrations for the analytes reported.

3.3.1 Quantitation Results of Target Analytes. The quantitative-analysis results for the target analyte volatile organic compounds were calculated directly from the calibration curve generated using the IS method described above and in PNL-TVP-03. The conversion from $\mathrm{ppbv}$ to $\mathrm{mg} / \mathrm{m}^{3}$ assumes standard temperature and pressure (STP) conditions of 760 torr and $273 \mathrm{~K}$ and was calculated directly from the following equation:

$$
\mathrm{mg} / \mathrm{m}^{3}=\frac{(\mathrm{ppbv} / 1000) \times \mathrm{g} \mathrm{mol} \mathrm{wt} \mathrm{of} \mathrm{compound}}{22.4 \mathrm{~L} / \mathrm{mol}}
$$

3.3.2 Identification and Quantitation of Tentatively Identified Compounds. The tentatively identified compounds (TICs) are determined by mass-spectral interpretation and comparison of the spectra with the EPA/NIST/WILEY Library, which is a part of the HP 5971 instrument operating system. Chromatographic peaks with an area count greater than, or equal to, one half of the total area count of the chlorobenzene- $d_{5}$ IS peak at the 20 -ppbv calibration level are tentatively identified and quantitatively estimated. This standard was chosen to determine the integration cutoff as it is in the middle of the chromatographic range and not in a region typically affected by coelution of other compounds. The quality of the mass-spectral searches was then reviewed by the principal investigators before the identification was assigned to each chromatographic peak.

The concentration of each TIC was estimated using a relative response factor calculated using a corrected total peak area for the IS chlorobenzene- $d_{s}$. Specifically, the total integrated area for the chlorobenzene- $\mathrm{d}_{5}$ peak had to be corrected for possible coeluting compounds before calculating the response factor. The corrected total peak area for the IS was calculated by multiplying the IS quantitation ion by a correction factor based on the ratio of the total integrated peak area to the quantitation ion as measured in blank runs. The corrected peak area was then used to calculate a response factor using the IS concentration in $\mathrm{mg} / \mathrm{m}^{3}$ :

$$
\text { Response Factor }=\frac{\text { IS conc. }\left(\mathrm{mg} / \mathrm{m}^{3}\right)}{\text { IS peak area }}
$$

The calculated response factor was then multiplied by the TIC peak area to give an estimated concentration for that compound. For butane, the total peak area was multiplied by the response 
factor for chlorobenzene- $d_{5}$ to give an estimated concentration of $1.75 \mathrm{mg} / \mathrm{m}^{3}$. Internal standards bromochloromethane and difluorobenzene were not used to quantitate the TICs because coeluting compounds appeared to have greatly altered the signal of the quantitation ions for those two ISs.

The ppbv concentrations are calculated from $\mathrm{mg} / \mathrm{m}^{3}$ and the molecular weight of the analyte.

$$
\text { TIC in ppbv }=\frac{\text { TIC }\left(\mathrm{mg} / \mathrm{m}^{3}\right) \times 22.4 \mathrm{~L} / \mathrm{mol} \times 1000}{\text { TIC } \mathrm{g} \mathrm{mol} \mathrm{wt}}
$$

The IS level added to all blank, standard, and sample injections was $18.3 \mathrm{ppbv}$ for bromochloromethane, $20.3 \mathrm{ppbv}$ for 1,4-difluorobenzene, and $18.2 \mathrm{ppbv}$ for chlorobenzene- $\mathrm{d}_{5}$. The IS concentrations were converted from ppbv to $\mathrm{mg} / \mathrm{m}^{3}$ at STP using a molecular weight of $129.39(\mathrm{~g} / \mathrm{mol})$ for bromochloromethane, 114.09 for 1,4-difluorobenzene, and 117.6 for chlorobenzene- $\mathrm{d}_{5}$.

\subsection{Analysis Results}

The results from the GC/MS analysis of the tank-headspace samples are presented in Tables 3.1 and 3.2. The results of GC/MS analysis of ambient air sample collected upwind of Tank BY-110 and through the VSS near Tank BY-110 are presented in Table 3.5. The GC/MS analysis results for permanent gases for both the ambient samples and from the tank headspace are presented in Table 3.6. A representative total ion chromatogram showing the identity of major constituents is given in Figure 3.1.

Table 3.1 lists the quantitative results for compounds listed as target analytes. Ten analytes were detected. Acetone at $25.7 \mathrm{mg} / \mathrm{m}^{3}$ contributed approximately $83 \%$ of the total mass.

Table 3.2 lists the semi-quantitative results for the TICs. The predominant species observed in this sample were butane $\left(1.75 \mathrm{mg} / \mathrm{m}^{3}\right)$, propene $\left(1.70 \mathrm{mg} / \mathrm{m}^{3}\right)$, pentane $\left(1.57 \mathrm{mg} / \mathrm{m}^{3}\right)$, 2-methylpentane $\left(1.19 \mathrm{mg} / \mathrm{m}^{3}\right)$, and propane $\left(1.12 \mathrm{mg} / \mathrm{m}^{3}\right)$. The normal paraffin hydrocarbons (NPHs), defined-as n-alkanes from $\mathrm{C}_{11}$ to $\mathrm{C}_{15}$, were also observed. It should be noted that because the SUMMA ${ }^{\text {th }}$ canisters were not heated at the time of analysis, the NPH concentrations listed after the retention time of decane may not be a true accounting of all the NPHs in the sample. Similarly, polar compounds, which may adhere to the inside surface of the canister, may also be under represented in this analysis. The total concentration of the TIC compounds was found to be 18.52 $\mathrm{mg} / \mathrm{m}^{3}$.

SUMMA $^{\text {th }}$ canister PNL 150 was analyzed in duplicate for target analytes and TICs to determine analytical precision. The analytical and relative percent difference (RPD) results are presented in Tables 3.3 and 3.4. Relative percent difference was calculated for analytes detected above the MDL and found in both replicates. Ten target analytes had RPDs of less than $10 \%$. Forty of the 43 TICs detected had RPDs of less than 10\%. The TICs 2-methyl-2-propanol, unknown $\mathrm{C}_{10}$ alkene/cycloalkane, and 2,6-dimethylundecane had RPDs greater than $10 \%$.

Table 3.5 list results of target analyte analyses for ambient air collected upwind of Tank BY110 and ambient air collected through the VSS. In the upwind sample, only one compound $(1,2,4$ trichlorobenzene) was detected. No TICs were observed in ambient air. 
Table 3.6 lists results of permanent gas analysis from samples collected from the headspace of Tank BY-110, ambient air collected $\sim 10 \mathrm{~m}$ upwind of the tank, and ambient air collected through the VSS. Permanent gases observed in the headspace were $\mathrm{CO}_{2}$ and $\mathrm{N}_{2} \mathrm{O}$. Carbon dioxide in the headspace was at a lower concentration than in ambient air. This may indicate a basic $(\mathrm{pH}>7.0)$ character of the tank constituents. Nitrous oxide was not detected either in the ambient air collected $\sim 10 \mathrm{~m}$ upwind of the Tank BY-110 or ambient air collected through the VSS. A replicate analysis was performed on one of the samples collected from this tank; however, only the results from the first analysis are reported. A replicate $\mathrm{H}_{2}$ analysis for one of the tank samples was performed. Hydrogen was not detected above the detection limit in either analysis. 


\subsection{Conclusions}

The concentrations of selected inorganic and organic compounds were determined from samples of the headspace of Tank BY-110 on 11/11/94. Sampling and analysis methods followed those described by Ligotke et al. (1994) for samples obtained from C-103, a tank containing a relatively complex headspace composition. Method-validation measurements during that study did appear to validate the trapping and analysis of $\mathrm{NH}_{3}$, but did not eliminate the possibility of interferences that could affect $\mathrm{NO}_{x}$ results. It is recommended that additional control samples be obtained if a tank is discovered in the future to contain significant quantities of $\mathrm{NO}_{\mathrm{x}}$. In the current sample job, $\mathrm{NO}_{x}$ samples were obtained after first passing the sample flow through an $\mathrm{NH}_{3}$ trap. The average and standard deviation of the concentration results from inorganic sorbent trains were $401 \pm 15 \mathrm{ppmv}\left(\mathrm{NH}_{3}\right), \leq 0.05 \mathrm{ppmv}\left(\mathrm{NO}_{2}\right), \leq 0.09 \mathrm{ppmv}(\mathrm{NO})$, and $9.2 \pm 0.2 \mathrm{mg} / \mathrm{L}$ (vapor-mass concentration). The vapor-mass concentration is expected to consist largely of water vapor.

Organic analysis of the headspace samples from Tank BY-110 identified 10 target analytes above the 5-ppbv reporting cutoff and 46 TICs above the 10-ppbv reporting cutoff. The concentration of the compound target analytes accounted for $62 \%$ of the total compounds identified by both organic analyses. Acetone accounted for $83 \%$ of the target analytes as well as $52 \%$ of the total compounds identified by both analyses. Butane, the highest concentration TIC, was $9 \%$ of the total TIC concentration. The TIC analysis also identified numerous NPH type compounds as the predominant species present in the tank-headspace samples. Two permanent gases, $\mathrm{CO}_{2}$ and $\mathrm{N}_{2} \mathrm{O}$, were also detected in the tank-headspace samples. The results of the ambient air sample collected $\sim 10 \mathrm{~m}$ upwind of Tank BY-110 identified one target analyte (1,2,4-trichlorobenzene) and no TICs. No compounds were detected in the ambient air sample collected through the VSS.

\subsection{References}

Clauss, T. W., M. W. Ligotke, B. D. McVeety, K. H. Pool, R. B. Lucke, J. S. Fruchter, and S. C. Goheen. 1994. Vapor Space Characterization of Waste Tank 241-BY-104: Results from Samples Collected on 6/24/94. PNL-10208. Pacific Northwest Laboratory, Richland, Washington.

Ligotke, M. W., K. H. Pool, and B. D. Lemer. 1994. Vapor Space Characterization of Waste Tank 241-C-103: Inorganic Results from Sample Job 7B (5/12/94 - 5/25/94). PNL-10172, Pacific Northwest Laboratory, Richland, Washington. 
.

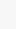




\subsection{Further Reading}

Pacific Northwest Laboratory. Analytical Laboratory Procedure Compendium. Procedures PNL-ALO-212, -226, -271. PNL-MA-599, Richland, Washington.

Pacific Northwest Laboratory. Quality Assurance Manual, Part 2: Good Practices Standard. PNL-MA-70, Part 2, Richland, Washington.

Pacific Northwest Laboratory. Quality Assurance Plan for Activities Conducted by the Analytical Chemistry Laboratory (ACL). MCS-033, Analytical Chemistry Laboratory, Richland, Washington.

Pacific Northwest Laboratory. 1994. Determination of TO-14 Volatile Organic Compounds in Hanford Waste Tank Headspace Samples Using SUMMA ${ }^{\text {Tx }}$ Passivated Canister Sampling and Gas Chromatographic-Mass Spectrometry Analysis, PNL-TVP-03 (Rev. 0), PNL Technical Procedure, Richland, Washington.

Pacific Northwest Laboratory. 1994. Sample Shipping and Receiving Procedure - DRAFT for PNL Waste Tank Samples. PNL-TVP-07 (Rev. 0), PNL Technical Procedure, Richland, Washington. 


\begin{tabular}{|c|c|c|c|c|c|c|c|c|c|}
\hline (p) & (p) & $\varsigma>$ & $20^{\circ} 0>$ & $s>$ & $200>$ & $\varsigma>$ & $200>$ & 901 & $9-\angle 5-S 6$ \\
\hline (p) & (p) & $\varsigma>$ & $20^{\circ} 0>$ & $\varsigma>$ & $20^{\circ} 0>$ & $\varsigma>$ & $20^{\circ} 0>$ & 991 & $S-b E-6 L$ \\
\hline (p) & (p) & $\varsigma>$ & $20^{\circ} 0>$ & $\varsigma>$ & $20^{\circ} 0>$ & $\varsigma>$ & $200>$ & tol & $s-2 b-00 t$ \\
\hline & & & & & & & & 901 & $\varepsilon-2 \vdash-90 t$ \\
\hline (p) & (p) & $\varsigma>$ & $20^{\circ} 0>$ & $s>$ & $20.0>$ & $s>$ & $20^{\circ} 0>$ & 901 & $\varepsilon-8 \varepsilon-80 \mathrm{I}$ \\
\hline (p) & (p) & $\varsigma>$ & $200>$ & $s>$ & $200>$ & $\varsigma>$ & $20^{\circ} 0>$ & 901 & $\forall l b 001$ \\
\hline (p) & (p) & $\varsigma>$ & $\varepsilon 0^{\prime} 0>$ & $s>$ & $\varepsilon 0^{\circ} 0>$ & $s>$ & $\varepsilon 0^{\circ} 0>$ & ZII & $L-06-801$ \\
\hline (p) & (p) & $\varsigma>$ & $600>$ & $s>$ & $60^{\circ} 0>$ & $s>$ & $60^{\circ} 0>$ & 691 & $\vdash 8 I-L Z I$ \\
\hline (p) & (p) & $\varsigma>$ & $500>$ & $s>$ & $t(0) 0>$ & $s>$ & $100>$ & 981 & $\vdash \varepsilon 6-901$ \\
\hline (p) & (p) & $\varsigma>$ & $20^{\circ} 0>$ & $\varsigma>$ & $\tau(1)^{\prime}(0)>$ & $\varsigma>$ & $200>$ & 26 & $\varepsilon-88-80 \mathrm{I}$ \\
\hline (p) & (p) & $\varsigma>$ & $\varepsilon 0^{\circ} 0>$ & $\varsigma>$ & $\varepsilon 00>$ & $s>$ & $10^{\circ} 0>$ & $\tau \varepsilon I$ & $S=00-6 L$ \\
\hline (p) & $(p)$ & $s>$ & $200>$ & $s>$ & $20^{\circ} 0>$ & $s>$ & $20.0>$ & 011 & $9-20-19$ \\
\hline$(p)$ & (p) & $\leqq>$ & $200^{\circ} 0>$ & $\varsigma>$ & $2(0) 0>$ & $\varsigma>$ & $20^{\circ} 0>$ & 011 & $5-10-19$ \\
\hline (p) & (p) & $\varsigma>$ & $10^{\circ} 0>$ & $\varsigma>$ & $\varepsilon O^{\prime} 0>$ & $S>$ & $\varepsilon 0^{\circ} 0>$ & $0 \& !$ & $9-10-62$ \\
\hline (p) & (p) & $s>$ & $\varepsilon 0^{\circ} 0>$ & $s>$ & $\varepsilon 0^{\circ} 0>$ & $s>$ & $10^{\circ} 0>$ & ZII & $5-\angle 8-8 L$ \\
\hline (p) & (p) & $\varsigma>$ & $\varepsilon 0^{\circ} 0>$ & $s>$ & $\varepsilon 0^{\circ} 0>$ & $s>$ & $\mathrm{EO}^{\prime} \mathrm{O}>$ & ZSI & $s-\varepsilon z-9 s$ \\
\hline (p) & (p) & $\varsigma>$ & $200>$ & $s>$ & $20.0>$ & $\varsigma>$ & $20^{\circ} 0>$ & $8 L$ & $\tau-\varepsilon \vdash-l L$ \\
\hline (p) & (p) & $s>$ & $\varepsilon 0^{\circ} 0>$ & $s>$ & $\varepsilon 0^{\circ} 0>$ & $s>$ & $\mathrm{EO}^{\circ} \mathrm{O}>$ & ZEI & $9-55-12$ \\
\hline (p) & (p) & $s>$ & $20^{\circ} 0>$ & $s>$ & $20^{\circ} 0>$ & $s>$ & $20^{\prime} 0>$ & 86 & $\tau-90-\angle 01$ \\
\hline (p) & (p) & $s>$ & $20^{\circ} 0>$ & $\varsigma>$ & $20^{\circ} 0>$ & $s>$ & $20^{\circ} 0>$ & 811 & $\varepsilon-99-\angle 9$ \\
\hline (p) & (p) & $s>$ & $20^{\circ} 0>$ & $\varsigma>$ & $200>$ & $\varsigma>$ & $20^{\circ} 0>$ & 96 & $2-6 \varsigma-9 \$ 1$ \\
\hline (p) & (p) & $s>$ & $20^{\circ} 0>$ & $\varsigma>$ & $200>$ & $\varsigma>$ & $20^{\circ} 0>$ & 86 & $\varepsilon-b \varepsilon-\varsigma L$ \\
\hline (p) & (p) & $s>$ & $50^{\circ} 0>$ & $S^{\prime} L$ & $90^{\circ} 0$ & $\varsigma>$ & $100^{\circ} 0>$ & 981 & $|-\varepsilon|-9 L$ \\
\hline (p) & (p) & $s>$ & $200>$ & $\varsigma>$ & $20^{\circ} 0>$ & $s>$ & $20^{\circ} 0>$ & 68 & $\tau-60-\varsigma L$ \\
\hline (p) & (p) & $s>$ & $200>$ & $\varsigma>$ & $200>$ & $s>$ & $20^{\circ} 0>$ & 96 & $\vdash \varsigma \varepsilon-\varsigma L$ \\
\hline$\angle E^{\prime} O$ & $90^{\circ} \mathrm{Z}$ & 182 & $\tau L 1$ & SZE & $00^{\circ} 2$ & 100 & $9 \nabla^{\circ} \tau$ & $9 \varepsilon l$ & $569-s L$ \\
\hline (p) & (p) & $s>$ & $10^{\circ} 0>$ & $\varsigma>$ & $100>$ & $\varsigma>$ & $10^{\circ} 0>$ & 29 & $\varepsilon-00-\varsigma L$ \\
\hline (p) & (p) & $s>$ & $200>$ & $\varsigma>$ & $200>$ & $s>$ & $20^{\circ} 0>$ & 76 & $6-E 8-t b L$ \\
\hline (p) & (p) & $s>$ & $100>$ & $\varsigma>$ & $100>$ & $\varsigma>$ & $10^{\circ} 0>$ & to & $\forall 10-S L$ \\
\hline (p) & (p) & $s>$ & $100^{\circ} 0>$ & $\varsigma>$ & $\$ 0^{\prime} 0>$ & $s>$ & $600>$ & $0<!$ & $z-b 1-9 L$ \\
\hline (p) & (p) & $s>$ & $10^{\circ} 0>$ & $\varsigma>$ & $10^{\prime} 0>$ & $s>$ & $10^{\prime} 0>$ & $0 S^{\circ}$ & $E-\angle 8-b L$ \\
\hline (p) & (p) & $s>$ & $E 0^{\circ} 0>$ & $\varsigma>$ & $\varepsilon 0^{\circ} 0>$ & $s>$ & $80^{\circ} 0>$ & $0 Z I$ & $8-I L-S L$ \\
\hline$\overline{\text { Aब(IIS }}$ & ( & (กัपdป) & (cii/giil) & 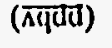 & $\left({ }_{\varepsilon}\right.$ [u/Jui $)$ & 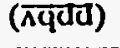 & 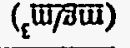 & MIOW & 'ONSVD \\
\hline \multicolumn{2}{|c|}{ 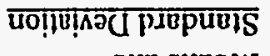 } & \multicolumn{2}{|c|}{ 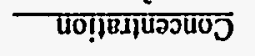 } & \multicolumn{2}{|c|}{ 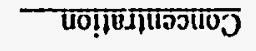 } & \multicolumn{2}{|c|}{ 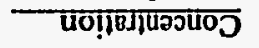 } & & \\
\hline \multicolumn{2}{|r|}{ puB subכN } & (a) $I S I^{\circ} 6$ & $\begin{array}{l}S I \text { INd } \\
-\tau L O b S\end{array}$ & \multicolumn{2}{|c|}{$\begin{array}{r}(0) 0 S 1 ' \mathrm{Wd} \\
(q) S I^{\circ} 80 \mathrm{~V}-\tau L O b S\end{array}$} & \multicolumn{2}{|c|}{$\begin{array}{r}(06 t l \text { TNd } \\
+I \angle 0 \forall-\tau L O b S\end{array}$} & & \\
\hline
\end{tabular}

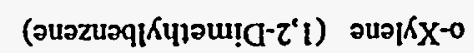

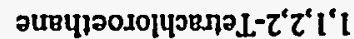
วนวมК1S .

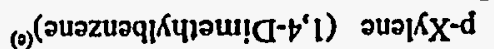

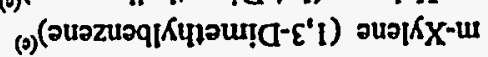

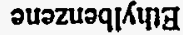
วนวzuəqุoso|บว

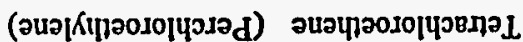

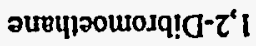

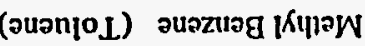
วนвน|วо이ำ

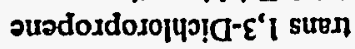

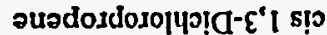

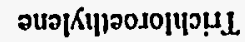

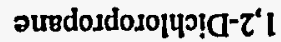

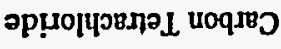
วนขวuəg

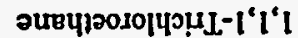

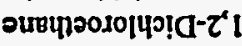

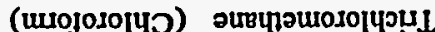

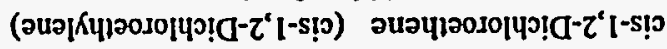

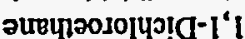

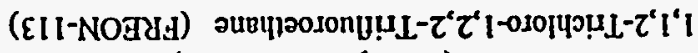

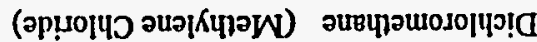

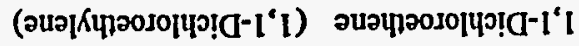

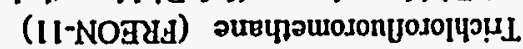
วрนัำว โКบเด

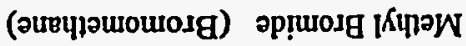

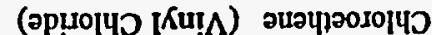

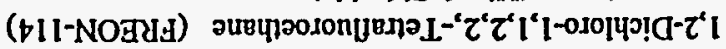

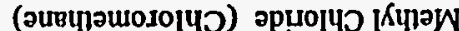

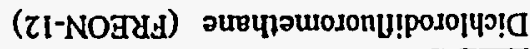
गयाष्ण 
Table $3.1 \quad$ (Contd)

\begin{tabular}{|c|c|c|c|c|c|c|c|c|c|}
\hline \multirow[b]{2}{*}{ CAS No. } & \multirow[b]{2}{*}{ Mol Wt } & \multicolumn{2}{|c|}{$\begin{array}{l}\text { S4072-A07.149(b) } \\
\text { PNL 149(c) } \\
\text { Concentration } \\
\end{array}$} & \multicolumn{2}{|c|}{$\begin{array}{l}\text { S4072-A08.150(0) } \\
\text { PNL } 150^{(6)} \\
\text { Concentration } \\
\end{array}$} & \multicolumn{2}{|c|}{$\begin{array}{l}\text { S4072-A09.151 } \\
\text { PNI } 151^{(c)} \\
\text { Concentration } \\
\end{array}$} & \multicolumn{2}{|c|}{$\begin{array}{l}\text { Means and } \\
\text { Standard Deviation }\end{array}$} \\
\hline & & $\left(\mathrm{mg} / \mathrm{m}^{3}\right)$ & (ppbv) & $\left(\mathrm{mg} / \mathrm{m}^{3}\right)$ & (pplov) & $\left(\mathrm{mg} / \mathrm{m}^{3}\right)$ & (pphv) & $\left(\mathrm{mg} / \mathrm{m}^{3}\right)$ & St Dev \\
\hline $108-67-8$ & 120 & $<0.03$ & $<5$ & $<0.03$ & $<s$ & $<0.03$ & $<5$ & (d) & (d) \\
\hline $95-63-6$ & 120 & $<0.03$ & $<5$ & $<0.03$ & $<5$ & $<0.03$ & $<5$ & (d) & (d) \\
\hline $100-44-7$ & 126 & $<0.03$ & $<5$ & $<0.03$ & $<5$ & $<0.03$ & $<5$ & (d) & (d) \\
\hline $541-73-1$ & 146 & $<0.03$ & $<5$ & $<0.03$ & $<5$ & $<0.03$ & $<5$ & (d) & (d) \\
\hline $106-46-7$ & 146 & $<0.03$ & $<5$ & $<0.03$ & $<5$ & $<0.03$ & $<5$ & (d) & (d) \\
\hline $95-50-1$ & 146 & $<0.03$ & $<5$ & $<0.03$ & $<5$ & $<0.03$ & $<5$ & (d) & (d) \\
\hline $120-82-1$ & 180 & 0.13 & 16.1 & 0.13 & 15.9 & 0.13 & 15.7 & 0.13 & 0.00 \\
\hline $87-68-3$ & 258 & $<0.60$ & $<5$ & $<0.60$ & $<5$ & $<0.60$ & $<5$ & (d) & (d) \\
\hline $78-93-3$ & 72 & 1.58 & 490 & 1.49 & 464 & 1.56 & 486 & 1.54 & 0.05 \\
\hline $67-64-1$ & 58 & 32.6 & 12557 & 24.9 & 9598 & 19.6 & 7571 & 25.7 & 6.50 \\
\hline $75-05-8$ & 41 & $<0.01$ & $<5$ & $<0.01$ & $<5$ & $<0.01$ & $<5$ & (d) & (d) \\
\hline $123-72-8$ & 72 & $<0.02$ & $<5$ & $<0.02$ & $<5$ & $<0.02$ & $<5$ & (d) & (d) \\
\hline $142-82-5$ & 100 & 0.48 & 108 & 0.47 & 105 & 0.49 & 110 & 0.48 & 0.01 \\
\hline $109-99-9$ & 72 & 0.49 & 152 & 0.48 & 148 & 0.49 & 151 & 0.49 & 0.01 \\
\hline $110-86-1$ & 79 & 0.16 & 46.1 & 0.15 & 41.8 & 0.15 & 42.5 & 0.15 & 0.01 \\
\hline $109-74-0$ & 69 & $<0.02$ & $<5$ & $<0.02$ & $<5$ & $<0.02$ & $<5$ & (d) & (d) \\
\hline $110-82-7$ & 84 & 0.09 & 23.7 & 0.07 & 19.9 & 0.07 & 18.7 & 0.08 & 0.01 \\
\hline $124-18-5$ & 142 & 0.22 & 34.9 & 0.2 & 31.2 & 0.19 & 29.1 & 0.20 & 0.02 \\
\hline $110-54-3$ & 86 & 0.14 & 36.4 & 0.02 & 4.85 & 0.04 & 10.9 & 0.07 & 0.06 \\
\hline $108-10-1$ & 100 & 0.04 & 9.24 & 0.04 & 9.33 & 0.05 & 10.4 & 0.04 & 0.01 \\
\hline $107-12-0$ & 55 & $<0.01$ & $<5$ & $<0.01$ & $<5$ & $<0.01$ & $<5$ & (d) & (d) \\
\hline $108-94-1$ & 98 & $<0.02$ & $<5$ & $<0.02$ & $<5$ & 0.25 & 57.1 & (d) & (d) \\
\hline $71-23-8$ & 60 & $<0.01$ & $<5$ & $<0.01$ & $<5$ & $<0.01$ & $<5$ & (d) & (d) \\
\hline
\end{tabular}

Analyte

1,3,5-Trimethylbenzene

1,2,4-Trimethylbenzene

Chloromethylbenzene, alpha (Benzyl Chloride)

m-Dichlorobenzene (1,3-Dichlorobenzene)

p-Dichlorobenzene (1,4-Dichlorobenzene)

o-Dichlorobenzene (1,2-Dichlorobenzene)

1,2,4-Trichlorobenzene

Hexachloro-1,3-Butadiene

2-Butanone

Acetone

Acetonitrile

N Butanal

Heptane

Tetrahydrofuran

Pyridine

Butanenitrile

Cyclohexane

Decane

4-Methyl-2-Pentanone

Propanenitrile

Cyclohexanone

Propanol

(a) TO-14 plus 15 additonal target analytes.

(b) WHC sample identification number.

(c) PNL canister number.

(d) Average and standard deviation are not meaningful for this analyte.

(e) $\mathrm{m}$-Xylene and $\mathrm{p}$-Xylene coelute; the reported concentration is the sum of these two compounds.

PNL $150^{(a)}$

$<0.03$

$<0.03$

$<0.03$

0.13

24.9

$<0.02$

$<0.02$

0.2

0.0

$<0.01$

$<0.01$
PNI. 151

Concentratio (d)

(d)

0.00

(d)

50

(d)

0.01

0.01

0.02

(d)

(d) 
Table 3.2 Tentatively Identified Compounds and Estimated Concentrations ${ }^{(\mathfrak{)})}$ of Samples from the Ileadspace of Tunk BY-110 in SIMMA ${ }^{\text {TM }}$ Canisters Collected on $11 / 11 / 94$

Tentatively

Identified Compound ${ }^{(e)}$

Propene

Propane

Cyclopropane

Isobutane

1-Butene

Butane

2-Methyl-1-Propene

Ethanol

2-Methyl-1-Butene

Isopropyl Alcohol

$\approx$ 1-Pentene

Pentane

2-methyl-2-Propanol

4-Methyl-1-Pentene

2-Methylpentane

Butanal

3-Methylpentane

1-Hexene

Methylcyclopentane

Unknown Ketone

1-Butanol

2-Pentanone

Unknown C7 Alkane

1-Heptene

Unknown Alcohol

Unknown

Unknown C8 Alkane

2-Hexanone

Octane
S4082-A07.149(b)

\begin{tabular}{|c|c|c|c|c|}
\hline & Mol & Ret & PNL $149^{(d)}$ & \\
\hline CAS No $^{(c)}$ & $\underline{W t}$ & Time & $\left(\mathrm{mg} / \mathrm{m}^{3}\right)$ & (ppbv) \\
\hline $115-07-1$ & 42 & 3.9 & 2.36 & 1259 \\
\hline $74-98-6$ & 44 & 4.0 & 1.62 & 823 \\
\hline $75-19-4$ & 42 & 4.7 & 0.36 & 189 \\
\hline $75-28-5$ & 58 & 5.1 & 0.74 & 284 \\
\hline $106-98-9$ & 56 & 5.7 & 1.28 & 510 \\
\hline $106-97-8$ & 58 & 5.9 & 2.41 & 929 \\
\hline $115-11-7$ & 56 & 6.2 & 0.35 & 141 \\
\hline $64-17-5$ & 46 & 7.2 & 0.26 & 127 \\
\hline $563-46-2$ & 70 & 7.8 & 0.17 & 54.7 \\
\hline $67-63-0$ & 60 & 9.0 & $<0.03$ & $<10$ \\
\hline $109-67-1$ & 70 & 9.1 & 0.94 & 300 \\
\hline $109-66-0$ & 72 & 9.6 & 2.32 & 723 \\
\hline $75-65-0$ & 74 & 10.22 & 0.14 & 41.5 \\
\hline $691-37-2$ & 84 & 12.4 & 0.20 & 54.1 \\
\hline $107-83-5$ & 86 & 13.1 & 1.54 & 401 \\
\hline $123-72-8$ & 72 & 13.2 & 0.18 & 54.8 \\
\hline $96-14-0$ & 86 & 13.8 & 0.31 & 81.5 \\
\hline $592-41-6$ & 84 & 14.0 & 0.26 & 69.9 \\
\hline \multirow[t]{2}{*}{$96-37-7$} & 84 & 16.4 & 0.19 & 50.7 \\
\hline & 86 & 17.0 & 0.15 & 38.0 \\
\hline $71-36-3$ & 74 & 17.4 & 0.64 & 193 \\
\hline \multirow{2}{*}{$107-87-9$} & 86 & 18.5 & 0.88 & 230 \\
\hline & 100 & 19.0 & 0.49 & 110 \\
\hline \multirow[t]{4}{*}{$592-76-7$} & 98 & 19.7 & 0.13 & 29.9 \\
\hline & & 21.5 & 0.08 & (g) \\
\hline & & 22.4 & 0.07 & (g) \\
\hline & .114 & 24.0 & 0.29 & 56.6 \\
\hline $591-78-6$ & 100 & 24.2 & 0.29 & 64.5 \\
\hline $11-65-9$ & 114 & 25.8 & 0.27 & 52.3 \\
\hline
\end{tabular}

S4082-A08.150(0),(c)

PNL $150^{(d)}$

PNL $151^{(\mathrm{d})}$

PNI. $151^{(d)} \quad$ Standard Deviations

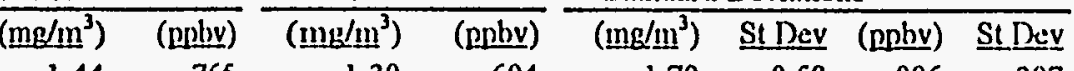

$\begin{array}{llllllll}1.44 & 765 & 1.30 & 694 & 1.70 & 0.58 & 906 & 307 \\ 0.96 & 488 & 0.79 & 404 & 1.12 & 0.44 & 572 & 222\end{array}$

$\begin{array}{ll}0.22 & 119 \\ 0.46 & 177\end{array}$

0.46

0.82

1.50

0.23

0.16

0.09

$<0.03$

0.54

1.29

0.08

0.13

1.00

0.11

34.5

$0.21 \quad 54.4$

$0.17 \quad 46.4$

$\begin{array}{ll}0.13 & 34.7\end{array}$

$0.14 \quad 36.5$

$0.58 \quad 174$

$0.78 \quad 203$

$0.47 \quad 104$

$0.13 \quad 28.8$

$<10$

0.08

0.28

0.30

0.27
0.20

0.41

0.75

1.35

0.20

0.14

0.08

0.17

0.28

1.11

0.07

0.13

1.02

0.11

() 21

0.18

0.12

0.13

0.55

0.77

0.47

0.13

0.07

0.07

0.29

0.30

0.27

\section{4}

108

160

299

521

81.6

69.1

25.3

63.5

90.6

345

22.1

35.2

266

35.2

55.0

47.5

31.5

34.4

168

200

106

28.8

$<10$

(8)

56.8

67.0
53.6
Means and

$\begin{array}{llll}0.26 & 0.08 & 139 & 44.2\end{array}$

$\begin{array}{lllll}0.54 & 0.17 & 207 & 67.5\end{array}$

$\begin{array}{llll}0.95 & 0.29 & 380 & 114\end{array}$

$\begin{array}{llll}1.75 & 0.57 & 677 & 220\end{array}$

$\begin{array}{llll}0.26 & 0.08 & 104 & 32.2\end{array}$

$\begin{array}{llll}0.19 & 0.06 & 90.7 & 31.3\end{array}$

$\begin{array}{llll}0.11 & 0.05 & 36.2 & 16.2\end{array}$

(f) (f) (f) (I)

$\begin{array}{llll}0.59 & 0.33 & 187 & 106\end{array}$

$\begin{array}{llll}1.57 & 0.66 & 489 & 204\end{array}$

$\begin{array}{llll}0.10 & 0.03 & 29.6 & 10.4\end{array}$

$\begin{array}{llll}0.16 & 0.04 & 41.4 & 11.0\end{array}$

$\begin{array}{llll}1.19 & 0.30 & 310 & 79.1\end{array}$

$\begin{array}{llll}0.13 & 0.04 & 41.5 & 11.5\end{array}$

$\begin{array}{llll}0.24 & 0.06 & 63.6 & 15.5\end{array}$

$\begin{array}{llll}0.20 & 0.05 & 54.6 & 13.3\end{array}$

$\begin{array}{llll}0.15 & 0.04 & 38.9 & 10.3\end{array}$

$\begin{array}{llll}0.14 & 0.01 & 36.3 & 1.8\end{array}$

$\begin{array}{llll}0.59 & 0.04 & 178 & 12.9\end{array}$

$\begin{array}{llll}0.81 & 0.06 & 211 & 16.6\end{array}$

$\begin{array}{llll}0.48 & 0.01 & 107 & 3.0\end{array}$

$\begin{array}{llll}0.13 & 0.00 & 29.2 & 0.7\end{array}$

(f) $\quad$ (I) $\quad$ (f) $\quad$ (f)

$\begin{array}{llll}0.07 & 0.00 & \text { (f) } & \text { (f) }\end{array}$

$\begin{array}{llll}0.29 & 0.00 & 56.2 & 0.9\end{array}$

$\begin{array}{llll}0.29 & 0.01 & 65.9 & 1.2\end{array}$

$\begin{array}{llll}0.27 & 0.00 & 52.7 & 0.8\end{array}$ 
Table $3.2 \quad$ (Contd)

Tentatively

Identified Compound $^{(e)}$

Unknown C9 Alkane

Unknown C9 Alkene/Cycloalkane

3-Heptanone

2-Heptanone

Nonane

Unknown Ketone

2-Octanone

Unknown C11 Alkane

Unknown C10 Alkene/Cycloalkane

- Undecane

ज) Unknown C11 Alkene/Cycloalkane

Unknown C12 Alkane

Dodecane

Undecane, 2,6-dimethyl-

Unknown C13 Alkene/Cycloalkane

Unknown C14 Alkane

Tridecane

Unknown C14 Alkane

Unknown C13 Alkene/Cycloalkane

Unknown C15 Alkane

Tetradecane
S4082-A07.149(b)

\begin{tabular}{|c|c|c|c|c|}
\hline \multirow{3}{*}{ CAS No. } & \multirow{2}{*}{$\begin{array}{l}\text { Mol } \\
\text { Wt }\end{array}$} & \multirow{2}{*}{$\begin{array}{l}\text { Ret } \\
\text { Time }\end{array}$} & \multicolumn{2}{|l|}{ PNL $149^{(d)}$} \\
\hline & & & $\left(\mathrm{mg} / \mathrm{m}^{3}\right)$ & (pplov) \\
\hline & 128 & 27.4 & 0.10 & 17.5 \\
\hline & 126 & 28.3 & $<0.06$ & $<10$ \\
\hline $106-35-4$ & 114 & 29.3 & 0.42 & 83.1 \\
\hline $110-43-0$ & 114 & 29.5 & 0.23 & 46.0 \\
\hline $111-84-2$ & 128 & 30.9 & 0.21 & 35.9 \\
\hline & 128 & 32.7 & 0.25 & 44.3 \\
\hline $111-13-7$ & 128 & 34.4 & 0.08 & 14.2 \\
\hline & 156 & 36.8 & 0.14 & 20.2 \\
\hline & 140 & 37.7 & 0.11 & 16.8 \\
\hline $1120-21-4$ & 156 & 40.0 & 0.41 & 58.2 \\
\hline & 154 & 42.1 & 0.07 & 10.3 \\
\hline & 170 & 42.7 & 0.07 & 8.6 \\
\hline $112-40-3$ & 170 & 44.1 & 0.58 & 76.3 \\
\hline $17301-23-4$ & 184 & 44.7 & 0.28 & 33.8 \\
\hline & 182 & 46.1 & 0.17 & 20.8 \\
\hline & 198 & 47.0 & 0.32 & 36.3 \\
\hline $629-50-5$ & 184 & 47.8 & 0.52 & 62.9 \\
\hline & 198 & 48.6 & 0.07 & 8.4 \\
\hline & 182 & 50.0 & 0.07 & 8.0 \\
\hline & 212 & 50.7 & 0.23 & 24.0 \\
\hline $29-59-4$ & 198 & 5.1 .4 & 0.27 & 31.0 \\
\hline
\end{tabular}

S4082-A08.150 PNL. $150^{\text {(d) }}$ (mg/1113) (Luby)

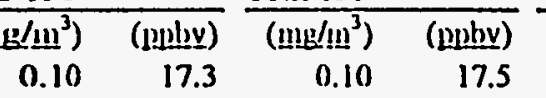

$0.06 \quad 11.4$

$0.41 \quad 80.2$

$0.23 \quad 45.0$

$0.20 \quad 34.5$

$0.23 \quad 40.6$

$0.07 \quad 12.4$

$0.12 \quad 17.7$.

$0.07 \quad 11.8$

$0.36 \quad 52.3$

$<0.07<10$

$<0.08$

0.53

0.28

0.15

0.29

0.48

0.07

0.07

0.21

0.25
S4082-A09.151(b) PNL: $151^{(0)}$

$\begin{array}{ll}0.10 & 17.5 \\ 0.06 & 11.4\end{array}$

$0.42 \quad 82.1$

$\begin{array}{ll}0.23 & 44.2\end{array}$

$0.20 \quad 34.8$

$0.24 \quad 41.7$

$0.07 \quad 12.3$

$0.12 \quad 17.4$

$0.10 \quad 15.4$

$0.35 \quad 50.5$

$<0.07<10$

$<0.08<10$

(1.4)

0.24

0.14

0.27

0.44

$<0.09$

$<0.08$

0.19

0.24
Means and

Standard Deviations

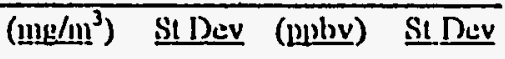

$\begin{array}{llll}0.10 & 0.00 & 17.4 & 0.1 \\ 0.06 & 0.00 & 11.4 & 0.0\end{array}$

0.42

$\begin{array}{llll}0.23 & 0.00 & 45.1 & 0.9\end{array}$

$\begin{array}{llll}0.20 & 0.00 & 35.1 & 0.7\end{array}$

$\begin{array}{llll}0.24 & 0.01 & 42.2 & 1.9\end{array}$

$\begin{array}{llll}0.07 & 0.01 & 13.0 & 1.1\end{array}$

$\begin{array}{llll}0.13 & 0.01 & 18.4 & 1.6\end{array}$

$\begin{array}{llll}0.09 & 0.02 & 14.7 & 2.6\end{array}$

$\begin{array}{llll}0.37 & 0.03 & 53.7 & 4.0\end{array}$

(I) (I) (f) (I)

(I) (f) (f) (f)

$\begin{array}{llll}0.54 & 0.04 & 70.5 & 5.7\end{array}$

$\begin{array}{llll}0.27 & 0.02 & 32.3 & 2.8\end{array}$

$\begin{array}{llll}0.15 & 0.02 & 18.7 & 2.1\end{array}$

$\begin{array}{llll}0.30 & 0.02 & 33.4 & 2.7\end{array}$

$\begin{array}{llll}0.48 & 0.04 & 58.0 & 4.9\end{array}$

$\begin{array}{llll}0.07 & 0.00 & 8.2 & 0.2\end{array}$

$\begin{array}{llll}0.07 & 0.00 & 8.2 & 0.3\end{array}$

$\begin{array}{llll}0.21 & 0.02 & 22.2 & 1.8\end{array}$

$\begin{array}{llll}0.25 & 0.02 & 28.7 & 2.2\end{array}$

(a) Semi-quantitative estimate calculated using concentration of closest eluting $\mathbb{D}$.

(b) WHC samplo identification number.

(c) Replicates of this sample are found in Table 3.3

(d) PNL SUMMA ${ }^{\text {TM }}$ canister number.

(e) Obtained by mass spectral interpretation amd comparison with the EPANIST/WMLEY Library.

(f) Average and standard deviation are not meaningful for this analyte.

(g) No molecular weight available for calculation. 
Table 3.3 Positively Identified and Quantitated TO-14 Target Analytes ${ }^{\left({ }^{()}\right.}$of Replicate Analyses of a Single SUMMA ${ }^{\text {Tn }}$ Canister Collected from the Headspace of Tank BY-110 on 11/11/94

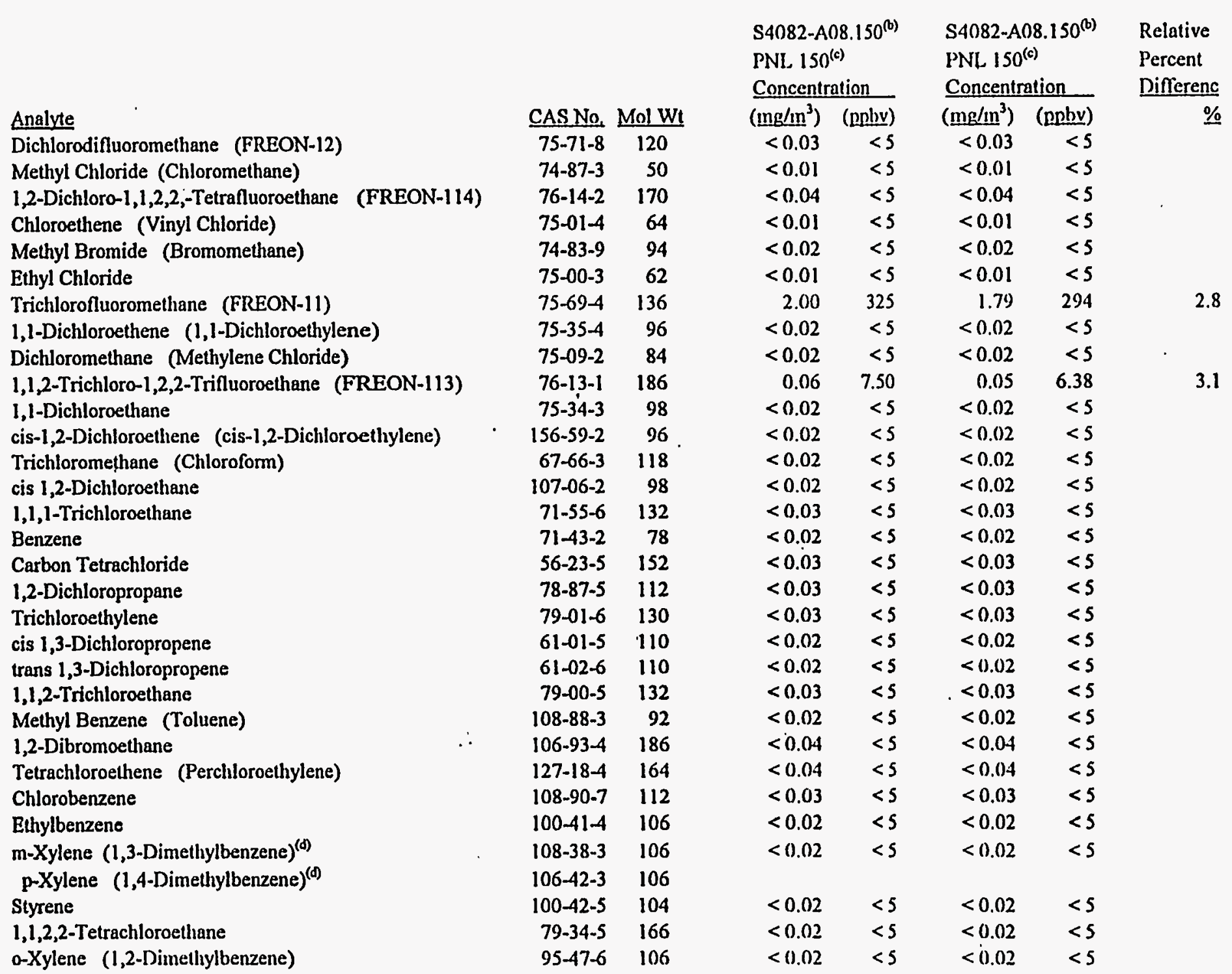


Table 3.3 (Contd)

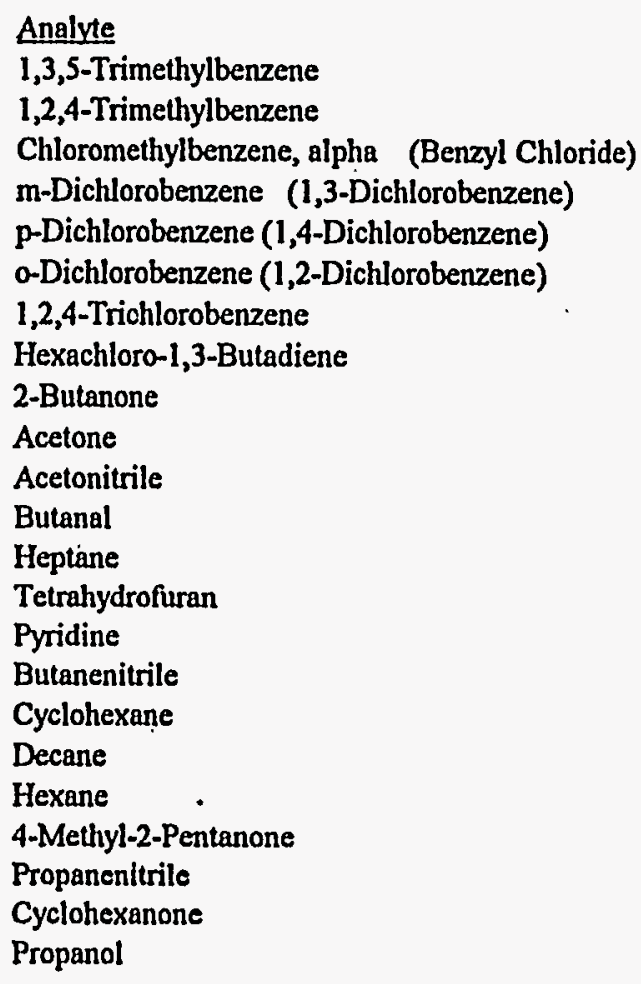

(a) TO-14 plus 15 additonal target analytes.

(b) WHC sample identification number.

(c) PNL canister number.

(d) $m$-Xylene and $p$-Xylene coelute; the reported concentration is the sum of these two compounds.

\begin{tabular}{|c|c|}
\hline \multicolumn{2}{|c|}{$\begin{array}{l}\text { S4082-A08.150 } \\
\text { PNL } 150^{(0)} \\
\text { Concentration }\end{array}$} \\
\hline$\left(\mathrm{mg} / \mathrm{m}^{3}\right)$ & (nphv) \\
\hline$<0.03$ & $<5$ \\
\hline$<0.03$ & $<5$ \\
\hline$<0.03$ & $<5$ \\
\hline$<0.03$ & $<5$ \\
\hline$<0.03$ & $<5$ \\
\hline$<0.03$ & $<5$ \\
\hline 0.13 & 15.9 \\
\hline$<0.60$ & $<5$ \\
\hline 1.49 & 464 \\
\hline 24.9 & 9598 \\
\hline$<0.01$ & $<5$ \\
\hline$<0.02$ & $<5$ \\
\hline 0.47 & 105 \\
\hline 0.48 & 148 \\
\hline 0.15 & 41.8 \\
\hline$<0.02$ & $<5$ \\
\hline 0.07 & 19.9 \\
\hline 0.20 & 31.2 \\
\hline 0.02 & 4.85 \\
\hline 0.04 & 9.33 \\
\hline$<0.01$ & $<5$ \\
\hline$<0.02$ & $<5$ \\
\hline$<0.01$ & $<5$ \\
\hline
\end{tabular}

S4082-A08.150(B) PNL $150^{(\text {(s) }}$

$\frac{\text { Concentration }}{\left(\mathrm{mg} / \mathrm{m}^{3}\right) \text { (nphv) }}$

CAS No, Mol W

$108-67-8 \quad 120$

$95-63-6 \quad 120$

$100-44-7 \quad 126$

541-73-1 $\quad 146$

$106-46-7 \quad 146$

95-50-1 146

120-82-1 180

87-68-3 258

78-93-3 72

67-64-1 58

75-05-8 41

123-72-8 72

142-82-5 100

109-99-9 72

110-86-1 79

109-74-0 69

$110-82-7 \quad 84$

124-18-5 $\quad 142$

$110-54-3 \quad 86$

108-10-1 100

107-12-0 55

108-94-1 98

$71-23-8 \quad 60$
$<0.03$ < $<5$

$<0.03<5$

$<0.03<5$

$<0.03<5$

$<0.03<5$

$<0.03<5$

$<0.04<5$

$<0.60<5$

$1.49 \quad 464$

$21.0 \quad 8110$

$<0.01<5$

$<0.02<5$

$0.48 \quad 108$

$0.48 \quad 149$

$0.13 \quad 37.7$

$<0.02<5$

$0.05 \quad 14.1$

$0.19 \quad 29.5$

$<0.02<5$

$0.03 \quad 6.05$

$<0.01<5$

$0.24 \quad 54.9$

$<0.01<5$
Relative

Percent

Differenc 
Table 3.4 Tentatively Identified Compounds and Estimated Concentrations ${ }^{\left({ }^{()}\right.}$of Replicate Analyses of a Single SUMMA ${ }^{\mathrm{TM}}$ Canister Collected from the Headspace of Tank BY-1 10 on 11/11/94

Tentatively

Identified Compound

Propene

Propane

Cyclopropane

Isobutane

1-Butene

Butane

2-Methyl-1-Propene

Bthanol

2-Methyl-1-Butene

1-Pentene

Pentane

2-Methyl-2-Propanol

4-Methyl-1-Pentene

2-Methylpentane

Butanal

3-Methylpentane

1-Hexene

Methylcyclopentane

Unknown Ketone

1-Butanol

2-Pentanone

Unknown C7 Alkane

1-Heptene

Unknown

Unknown C8 Alkane

2-Hexanone

Octane

Unknown C9 Alkane

Unknown C9 Alkene/Cycloalkane

3-Heptanone

2-Heptanone

Nonane

\begin{tabular}{|c|c|c|c|c|c|c|c|}
\hline \multirow[b]{2}{*}{$\mathrm{CAS} \mathrm{No}^{(\infty)}$} & \multirow{2}{*}{$\begin{array}{l}\text { Mol } \\
\text { Wt }\end{array}$} & \multirow{2}{*}{$\begin{array}{l}\text { Ret } \\
\text { Time }\end{array}$} & \multicolumn{2}{|c|}{$\begin{array}{l}\text { S4082-A08.150 } \\
\text { PNL } 150^{(\mathfrak{b})}\end{array}$} & \multicolumn{2}{|c|}{$\begin{array}{l}\text { S4082-A08.150(b) } \\
\text { PNL, } 150^{(c)}\end{array}$} & \multirow{2}{*}{$\begin{array}{l}\text { Relative } \\
\text { Percent } \\
\text { Difference } \\
\%\end{array}$} \\
\hline & & & $\left(\mathrm{mg} / \mathrm{m}^{3}\right)$ & $\overline{(p p l o v)}$ & $\left(\mathrm{mg} / \mathrm{m}^{3}\right)$ & $\overline{(\mathrm{ppliv})}$ & \\
\hline $115-07-1$ & 42 & 3.9 & 1.44 & 765 & 1.32 & 703 & 8.4 \\
\hline $74-98-6$ & 44 & 4.0 & 0.96 & 488 & 0.88 & 450 & 8.1 \\
\hline $75-19-4$ & 42 & 4.7 & 0.22 & 119 & 0.21 & 111 & 7.0 \\
\hline $75-28-5$ & 58 & 5.1 & 0.46 & 177 & 0.43 & 165 & 7.0 \\
\hline $106-98-9$ & 56 & 5.7 & 0.82 & 330 & 0.78 & 310 & 6.0 \\
\hline $106-97-8$ & 58 & 5.9 & 1.50 & 580 & 1.40 & 539 & 7.5 \\
\hline $115-11-7$ & 56 & 6.2 & 0.23 & 90.4 & 0.21 & 84.4 & 6.9 \\
\hline $64-17-5$ & 46 & 7.2 & 0.16 & 76.5 & 0.15 & 72.1 & 5.9 \\
\hline $563-46-2$ & 70 & 7.8 & 0.09 & 28.5 & 0.08 & 26.9 & 5.8 \\
\hline $109-67-1$ & 70 & 9.1 & 0.54 & 172 & 0.49 & 156 & 9.6 \\
\hline $109-66-0$ & 72 & 9.6 & 1.29 & 400 & 1.18 & 366 & 9.1 \\
\hline $75-65-0$ & 74 & 10.22 & 0.08 & 25.1 & 0.07 & 22.4 & 11.5 \\
\hline $691-37-2$ & 84 & 12.4 & 0.13 & 34.9 & 0.13 & 34.7 & 0.8 \\
\hline $107-83-5$ & 86 & 13.1 & 1.00 & 262 & 1.00 & 262 & 0.0 \\
\hline $123-72-8$ & 72 & 13.2 & 0.11 & 34.5 & 0.11 & 35.5 & 2.7 \\
\hline $96-14-0$ & 86 & 13.8 & 0.21 & 54.4 & 0.21 & 54.4 & 0.0 \\
\hline $592-41-6$ & 84 & 14.0 & 0.17 & 46.4 & 0.17 & 46.4 & 0.0 \\
\hline \multirow[t]{2}{*}{$96-37.7$} & 84 & 16.4 & 0.13 & 34.7 & 0.13 & 34.1 & 1.6 \\
\hline & 86 & 17.0 & 0.14 & 36.5 & 0.14 & 35.9 & 1.4 \\
\hline $71-36-3$ & 74 & 17.4 & 0.58 & 174 & 0.57 & 174 & 0.2 \\
\hline \multirow[t]{2}{*}{$107-87-9$} & 86 & 18.5 & 0.78 & 203 & 0.79 & 205 & 0.8 \\
\hline & 100 & 19.0 & 0.47 & 104 & 0.47 & 105 & 0.4 \\
\hline \multirow[t]{3}{*}{$592-76-7$} & 98 & 19.7 & 0.13 & 28.8 & 0.13 & 29.0 & 0.8 \\
\hline & & 22.4 & 0.08 & (e) & & & \\
\hline & 114 & 24.0 & 0.28 & 55.2 & 0.29 & 56.4 & 2.1 \\
\hline $591-78-6$ & 100 & 24.2 & 0.30 & 66.1 & 0.28 & 63.2 & 4.5 \\
\hline \multirow[t]{3}{*}{$111-65-9$} & 114 & 25.8 & 0.27 & 52.3 & 0.26 & 51.9 & 0.8 \\
\hline & 128 & 27.4 & 0.10 & 17.3 & 0.10 & 17.5 & 1.0 \\
\hline & 126 & 28.3 & 0.06 & 11.4 & & & \\
\hline $106-35-4$ & 114 & 29.3 & 0.41 & 80.2 & 0.41 & 80.2 & 0.0 \\
\hline $110-43-0$ & 114 & 29.5 & 0.23 & 45.0 & 0.22 & 43.0 & 4.5 \\
\hline $111-84-2$ & 128 & 30.9 & 0.20 & 34.5 & 0.19 & 33.4 & 3.1 \\
\hline
\end{tabular}


Tentatively

Identified Compound ${ }^{(d)}$

Unknown Ketone

2-Octanone

Unknown Cll Alkane

Unknown Cl0 Alkene/Cycloalkane

Undecane

Dodecane

2,6-Dimethylundecane,

Unknown C13 Alkene/Cycloalkane

Unknown C14 Alkane

Tridecane

Unknown Cl4 Alkane

Unknown C13 Alkene/Cycloalkane

Unknown C15 Alkane

Tetradecane

\begin{tabular}{|c|c|c|c|c|c|c|c|}
\hline \multirow[b]{2}{*}{ CAS No. ${ }^{(d)}$} & \multirow{2}{*}{$\begin{array}{l}\text { Mol } \\
\text { Wt }\end{array}$} & \multirow{2}{*}{$\begin{array}{l}\text { Ret } \\
\text { Time }\end{array}$} & \multicolumn{2}{|c|}{$\begin{array}{l}\text { S4082-A08.150 } \\
\text { PNL } 150^{(c)}\end{array}$} & \multicolumn{2}{|c|}{$\begin{array}{l}\text { S4082-A08.150(b) } \\
\text { PNL } 150^{(c)}\end{array}$} & \multirow{2}{*}{$\begin{array}{l}\text { Relative- } \\
\text { Percent } \\
\text { Difference } \\
\%\end{array}$} \\
\hline & & & $\left(\mathrm{mg} / \mathrm{m}^{3}\right)$ & $\overline{(n p b v)}$ & $\left(\mathrm{mg} / \mathrm{m}^{3}\right)$ & $\overline{(n p b v)}$ & \\
\hline & 128 & 32.7 & 0.23 & 40.6 & 0.23 & 39.6 & 2.6 \\
\hline \multirow[t]{3}{*}{$111-13-7$} & 128 & 34.4 & 0.07 & 12.4 & 0.07 & 12.4 & 0.0 \\
\hline & 156 & 36.8 & 0.12 & 17.7 & 0.12 & 17.4 & 1.6 \\
\hline & 140 & 37.7 & 0.07 & 11.8 & 0.09 & 14.9 & 22.8 \\
\hline $1120-21-4$ & 156 & 40.0 & 0.36 & 52.3 & 0.35 & 49.8 & 4.8 \\
\hline $112-40-3$ & 170 & 44.1 & 0.53 & 70.4 & 0.49 & 64.3 & 9.0 \\
\hline \multirow[t]{3}{*}{$17301-23-4$} & 184 & 44.7 & 0.28 & 34.1 & 0.24 & 29.1 & 15.8 \\
\hline & 182 & 46.1 & 0.15 & 18.7 & 0.15 & 17.8 & 4.7 \\
\hline & 198 & 47.0 & 0.29 & 32.9 & 0.28 & 31.1 & 5.7 \\
\hline \multirow[t]{4}{*}{$629-50-5$} & 184 & 47.8 & 0.48 & 57.9 & 0.45 & 54.9 & 5.4 \\
\hline & 198 & 48.6 & 0.07 & 8.0 & 0.07 & 7.5 & 7.3 \\
\hline & 182 & 50.0 & 0.07 & 8.4 & & & \\
\hline & 212 & 50.7 & 0.21 & 22.2 & 0.21 & 22.0 & 1.0 \\
\hline $629-59-4$ & 198 & 51.4 & 0.25 & 28.4 & 0.26 & 29.5 & 3.9 \\
\hline
\end{tabular}

(a) Semi-quantitative estimate calculated using concentration of closest eluting ID.

(b) WHC sample identification number.

(c) PNL SUMMA ${ }^{\mathrm{TM}}$ canister number

(d) Obtained by mass spectral interpretation amd comparison with the EPANIST/WILEY Library.

(e) No molecular weight available for calculation. 
Table 3.5 Positively Identified and Quantitated TO-14 Target Analytes ${ }^{())}$for Ambient Air Collected Near Tank BY-110 in SUMMA ${ }^{\text {TM }}$ Canisters on $11 / 1$ 1/94

\begin{tabular}{|c|c|c|c|c|}
\hline & & & $\begin{array}{l}\text { Upwind } \\
\text { S4082-A01.147(b) } \\
\text { PNL 147 } \\
\text { Concentration }\end{array}$ & $\begin{array}{l}\text { Through VSS } \\
\text { S4082-A02.148 } \\
\text { PNL 148 } \\
\text { Concentration }\end{array}$ \\
\hline Analyte & CAS No, & Mol Wt & $\left(\mathrm{mg} / \mathrm{m}^{3}\right)$ & $\left(\mathrm{mg} / \mathrm{m}^{3}\right)$ \\
\hline 1,2,4-Trichlorobenzene & $120-82-1$ & 181 & 0.10 & $<0.04$ \\
\hline
\end{tabular}

(a) TO-14 plus 15 additonal analytes.

(b) WHC sample identification number.

(c) PNL canister number. 
Table 3.6 Permanent Gas Analysis Results for Samples Collected from the Headspace of Tank BY-110 and for Ambient Air Collected Near Tank BY-110 in SUMMA ${ }^{\text {TM }}$ Canisters on 11/11/94

\begin{tabular}{|c|c|c|c|c|c|}
\hline & Ambient Air & \multicolumn{4}{|l|}{$\begin{array}{l}\text { Ambient Air } \\
\text { Through VSS }\end{array}$} \\
\hline & $\begin{array}{l}\text { Upwind } \\
\text { S4082-A01.147(1) }\end{array}$ & $\begin{array}{l}\text { Through VSS } \\
\text { S4082-A02.148(a) }\end{array}$ & S4082-A05.149(a) & $S 4082-A 05.150^{(())}$ & 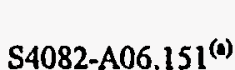 \\
\hline & PNL $147^{(b)}$ & PNL $148^{(b)}$ & PNL $149^{(b),(c)}$ & PNL $150^{(0)}$ & PNL $151^{(b)}$ \\
\hline $\begin{array}{l}\text { Permanent Gas } \\
\text { Analyte }\end{array}$ & $\begin{array}{l}\text { Concentration } \\
\text { (ppmv) }\end{array}$ & $\begin{array}{l}\text { Concentration } \\
\text { (ppmv) }\end{array}$ & $\begin{array}{l}\text { Concentration } \\
\text { (ppmv) }\end{array}$ & $\begin{array}{l}\text { Concentration } \\
\text { (ppmv) }\end{array}$ & $\begin{array}{l}\text { Concentration } \\
\text { (ppmv) }\end{array}$ \\
\hline Hydrogen & $<160$ & $<160$ & $<160$ & $<160$ & $<160$ \\
\hline Methane & $<61$ & $<61$ & $<61$ & $<61$ & $<61$ \\
\hline Carbon Dioxide & 384 & 397 & 277 & 173 & 238 \\
\hline Carbon Monoxide & $<76$ & $<76$ & $<76$ & $<76$ & $<76$ \\
\hline Nitrous Oxide & $<67$ & $<67$ & 104 & 125 & 81 \\
\hline
\end{tabular}

(a) WHC sample identification number

(b) PNL canister number.

(c) Replicate analysis for PNL 149 resulted in a concentration of 173 ppmv for $\mathrm{CO}_{2}$, and 160 ppmv for $\mathrm{N}_{2} \mathrm{O}$. 


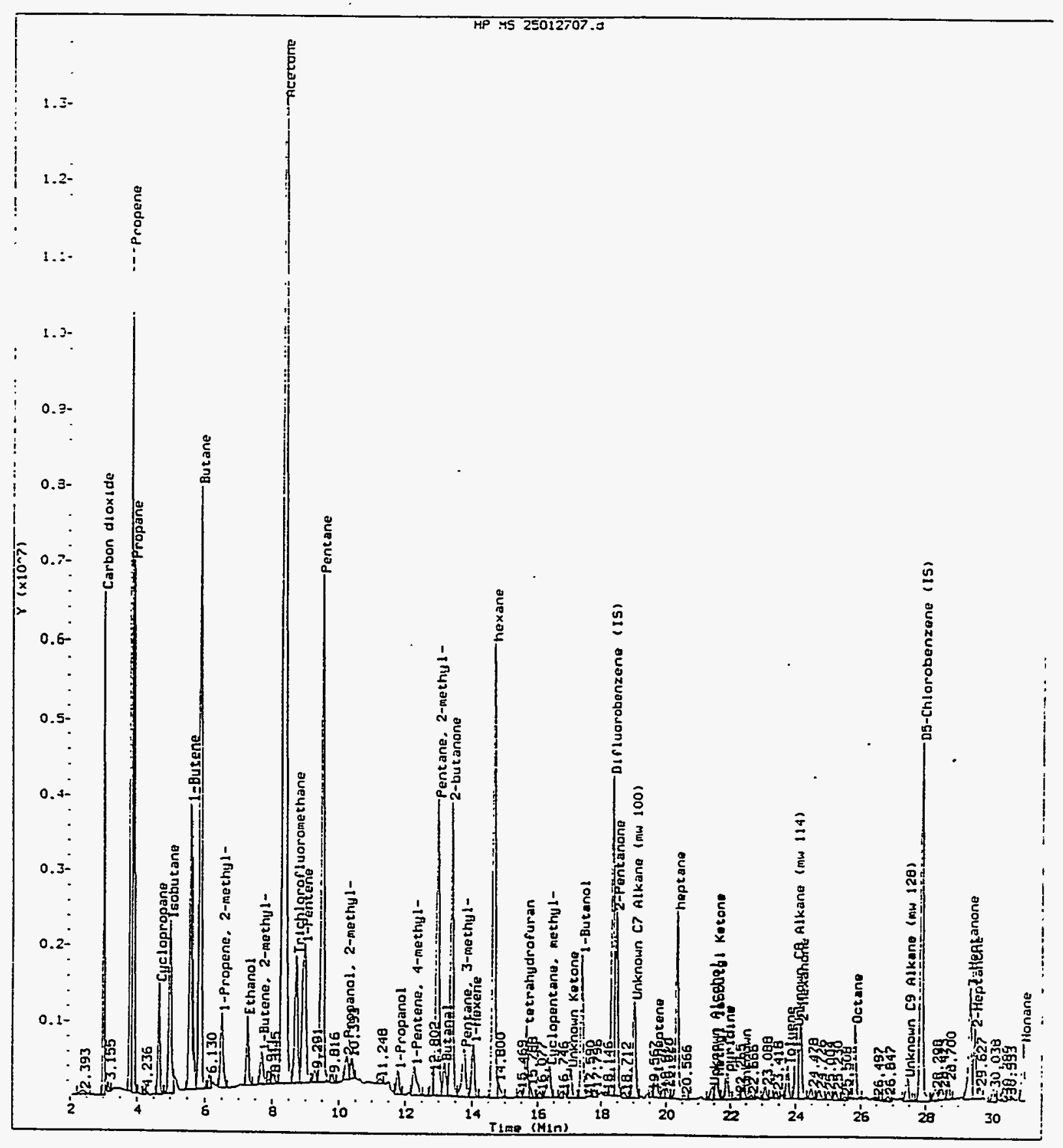

Figure 3.1a Total Ion Chromatogram (2 - $30 \mathrm{~min}$ ) for Hanford Waste Tank BY-110 SUMMA ${ }^{\text {Tx }}$ Canister Sample S4082-A07.149 Collected on 11/11/94 


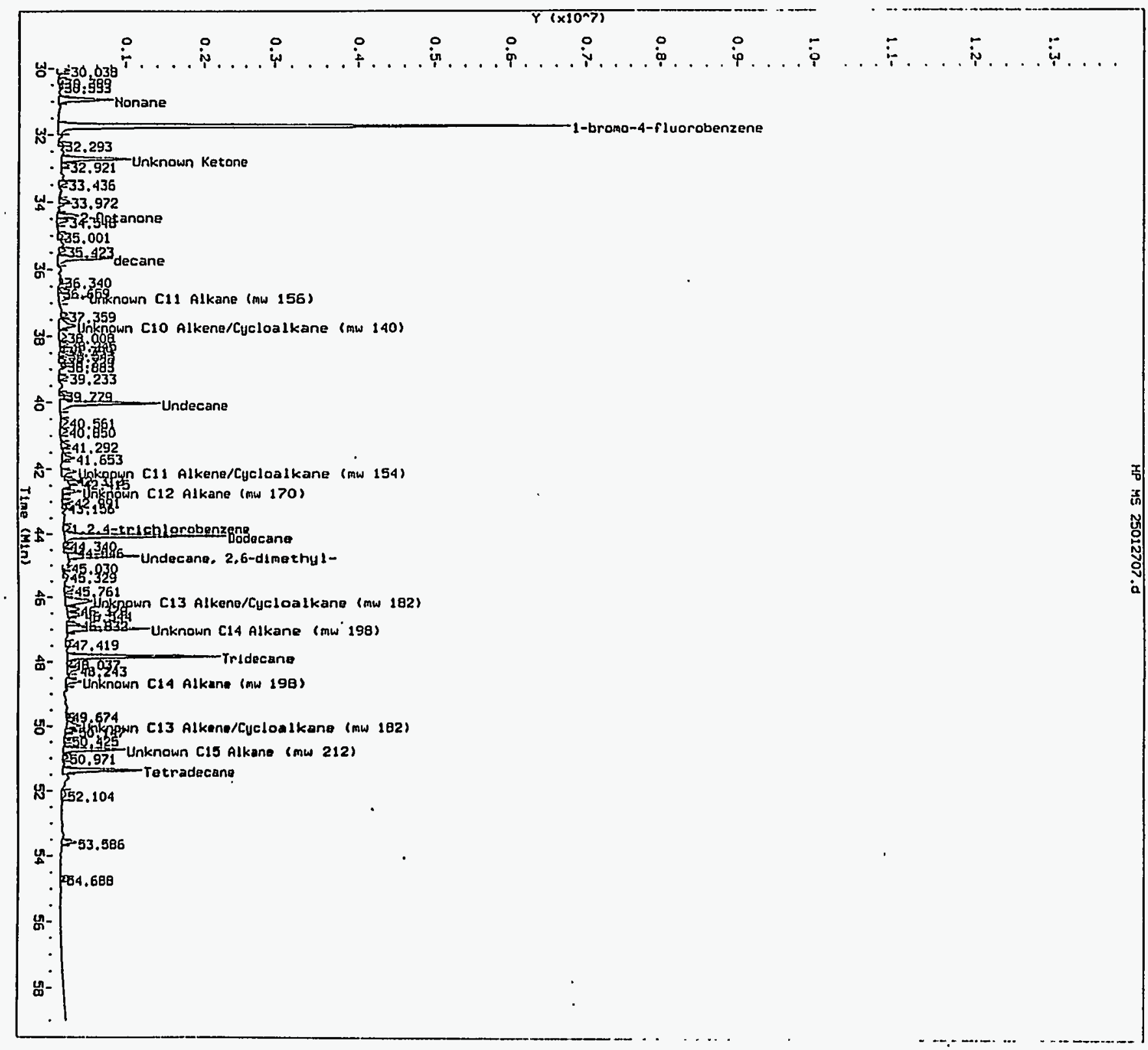




\section{Distribution}

No. of

Copies

Offsite

2 DOE Office of Scientific and Technical Information

\section{R. A. Jenkins}

Oak Ridge National Laboratory

P.O. Box 2008

-Building 4500-5, MS 6120

Oak Ridge, Tennessee 37831-6120
No. of

Copies

Onsite

2 DOE Richland Operations Office

J. M. Clark, S7-54

T. Noble, S7-54

Corps of Engineers

T. W. Gardner-Clayson, A5-19

4 Westinghouse Hanford Company

H. Babad, R2-78

D. R. Bratzel, S7-21 (2)

J. E. Meacham, S7-15

27 Pacific Northwest Laboratory

S. C. Goheen, P8-08 (20)

J. L. Huckaby, K6-55

M. W. Ligotke, P7-59

Technical Report Files (5)

Dist. 1 